\title{
Developing a Dynamic Web-GIS Based Landslide Early Warning System for the Chittagong Metropolitan Area, Bangladesh
}

\author{
Bayes Ahmed 1,*(1), Md. Shahinoor Rahman 2,3, Rahenul Islam ${ }^{4}$, Peter Sammonds ${ }^{1}$, \\ Chao Zhou ${ }^{5}$, Kabir Uddin ${ }^{6}(\mathbb{D})$ and Tahmeed M. Al-Hussaini ${ }^{3,7}$ \\ 1 Institute for Risk and Disaster Reduction, University College London (UCL), Gower Street, \\ London WC1E 6BT, UK; p.sammonds@ucl.ac.uk \\ 2 Center for Spatial Information Science and Systems, George Mason University, Fairfax, VA 22030, USA; \\ mrahma25@masonlive.gmu.edu \\ 3 BUET-Japan Institute of Disaster Prevention and Urban Safety (BUET-JIDPUS), Bangladesh University of \\ Engineering and Technology (BUET), Dhaka 1000, Bangladesh; htahmeed@yahoo.com \\ 4 International Centre for Diarrhoeal Disease Research, Bangladesh (icddr,b), Mohakhali, \\ Dhaka 1212, Bangladesh; rahen.rangan@gmail.com \\ 5 Engineering Faculty, China University of Geosciences, Wuhan 430074, China; zhouchao_rs@163.com \\ 6 Geospatial Solutions Theme, International Centre for Integrated Mountain Development (ICIMOD), \\ Kathmandu 44073, Nepal; kabir.uddin@icimod.org \\ 7 Department of Civil Engineering, Bangladesh University of Engineering and Technology (BUET), \\ Dhaka 1000, Bangladesh \\ * Correspondence: bayesahmed@gmail.com or bayes.ahmed@ucl.ac.uk
}

Received: 22 August 2018; Accepted: 15 December 2018; Published: 19 December 2018

\begin{abstract}
This article aims to develop a Web-GIS based landslide early warning system (EWS) for the Chittagong Metropolitan Area (CMA), Bangladesh, where, in recent years, rainfall-induced landslides have caused great losses of lives and property. A method for combining static landslide susceptibility maps and rainfall thresholds is proposed by introducing a purposely-build hazard matrix. To begin with, eleven factor maps: soil permeability; surface geology; landcover; altitude; slope; aspect; distance to stream; fault line; hill cut; road cut; and drainage network along with a detailed landslide inventory map were produced. These maps were used, and four methods were applied: artificial neural network (ANN); multiple regressions; principal component analysis; and support vector machine to produce landslide susceptibility maps. After model validation, the ANN map was found best fitting and was classified into never warning, low, medium, and high susceptibility zones. Rainfall threshold analysis (1960-2017) revealed consecutive 5-day periods of rainfall of 71-282 mm could initiate landslides in CMA. Later, the threshold was classified into three rainfall rates: low rainfall $(70-160 \mathrm{~mm})$, medium rainfall $(161-250 \mathrm{~mm})$, and high rainfall (>250 mm). Each landslide was associated with a hazard class (no warning vs. warning state) based on the assumption that the higher the susceptibility, the lower the rainfall. Finally, the EWS was developed using various libraries and frameworks that is connected with a reliable online-based weather application programming interface. The system is publicly available, dynamic, and replicable to similar contexts and is able to disseminate alerts five days in advance via email notifications. The proposed EWS is novel and the first of its kind in Bangladesh, and can be applied to mitigate landslide disaster risks.
\end{abstract}

Keywords: landslides; early warning system; remote sensing; GIS; susceptibility mapping; rainfall thresholds; disaster risk reduction 


\section{Introduction}

Disasters resulting from natural hazards account for casualties, human displacement, and property damage on a catastrophic scale around the world. Around 1388 disasters were reported worldwide from 2013-2016, and about 45\% of all those disasters occurred in Asia [1]. Landslides are recognized as the third type of most important natural hazard induced disaster worldwide [2]. Asia, in particular India, Nepal, China, and Japan, are most vulnerable to rainfall-induced landslide disasters [3-7]. For example, at least 200 people were killed and six million were evacuated due to landslides and flooding triggered by historic levels of torrential rainfall in Japan in July 2018 [8]. Landslide disasters were infrequent in densely populated Bangladesh in the past, but in recent years, increasing human activities such as indiscriminate hill cutting for slum and residential housing development has resulted in many landslides [9]. Rainfall-induced landslides now pose a severe threat in the Chittagong Hill Districts (CHD) of Bangladesh (Figure 1a). Devastating and fatal landslides have repeatedly hit CHD (see Appendix A, Table A1). People particularly those living on the steep slopes are highly vulnerable to landslide disasters [10-12]. On June 2017, a series of rainfall-triggered landslides caused 168 deaths and damaged 40 thousand houses in the Rangamati, Chittagong, and Bandarban districts leading to thousands of families needing refuge in different shelters. Up until now, this is considered as the biggest landslide disaster in Bangladesh. Another catastrophic landslide event in Chittagong Metropolitan Area (CMA) occurred on 11 June 2007, killing 128 people. These landslides were triggered by heavy rainfall $(610 \mathrm{~mm})$ over eight consecutive days [13].
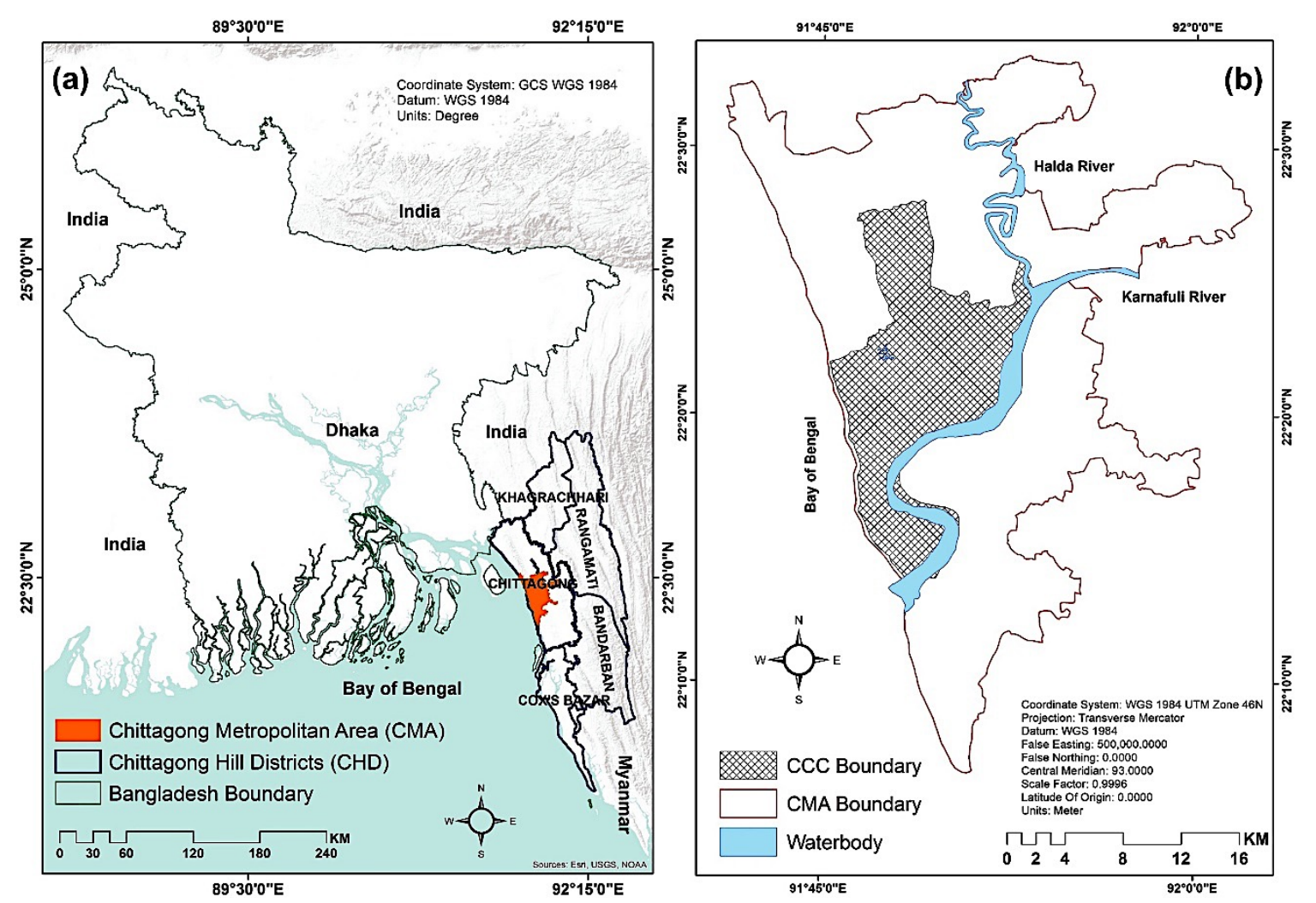

Figure 1. Location map of (a) Chittagong Hill Districts (CHD) in Bangladesh and (b) Chittagong Metropolitan Area (CMA), and Chittagong City Corporation (CCC).

Early warning systems (EWS) are necessary when standard structural mitigation measures fail or are absent [14-16]. EWSs are considered as essential tools for landslide disaster risk reduction [17] and can be operational at global, regional, and local scales [18,19]. EWSs for rainfall-induced landslides are contextual and the modeling phase depends on the correlation between landslide occurrences in the area of interest and rainfall events triggering the disasters $[20,21]$. Recently, the NASA Goddard 
Space Flight Center introduced a global satellite-based rainfall-induced landslide nowcasting system that is updated every $30 \mathrm{~min}$ and uses data from the Global Precipitation Measurement (GPM) mission [22]. An operational Web-GIS based landslide EWS for Tuscany, Italy, was developed at the regional scale by analyzing space-time variable rainfall thresholds [23]. There are many examples of rainfall intensity-duration and probabilistic antecedent rainfall threshold analyses for landslide EWSs [24-27]. However, rainfall is not the only contributor to landslides; other factors such as hill cutting and deforestation [10,12], soil's hydrological parameters [28], and antecedent soil moisture [29] contribute. At the city or local scales, warnings are typically disseminated zone-wise considering the spatial and temporal distribution of rainfall, landslides, and alert phases [20]. For warning zonation purpose landslide susceptibility mapping techniques have been effectively used [29-31]. In Bangladesh, the Ministry of Disaster Management and Relief under the Comprehensive Disaster Management Programme-II (CDMP-II) developed a community-based landslide EWS for the Cox's Bazar district in 2012 [32]. They conducted detailed landslide inventory surveying, rainfall threshold analysis (96 mm rainfall during $24 \mathrm{~h}$ or $185 \mathrm{~mm}$ rainfall in $48 \mathrm{~h}$ could initiate landslides), a series of community-based participatory activities and arranged training workshops with local people and stakeholders [33]. However, this EWS is no longer active, as no follow-up activities or long-term maintenance and monitoring system was recommended after the project's completion. Recently, in 2015, the Geological Survey of Bangladesh (GSB) set up four automated systems in Cox's Bazar and Chittagong to monitor and predict rainfall. They found that $100 \mathrm{~mm}$ of rainfall in $3 \mathrm{~h}$ or $200 \mathrm{~mm}$ rainfall in $24 \mathrm{~h}$ or $350 \mathrm{~mm}$ rainfall in 3 days could trigger landslides in the vicinity of the two cities. The weather stations are regularly updated and linked with an online database and can send SMS text messages to registered personnel. However, the system is not yet functional and publicly available, and requires improvements.

Over the past 20 years, landslide disasters were prominent in the CHD, particularly in CMA (Figure 1b). Despite being repeatedly hit by devastating landslides, the concerned authorities, like the Chittagong Development Authority (CDA), and the Chittagong City Corporation (CCC), have failed to mitigate landslide disaster risks in CMA. However, these two public organizations are solely responsible for the sustainable development, planning control, and ensuring citizen safety in CMA. Thousands of people are currently living on the dangerous hill-slopes in CMA and they have grave concerns during the monsoon season (May to September). Yet, the authorities have not produced a landslide hazard zonation map, nor an effective landslide alert system. To overcome such limitations, this article aims to produce a scientifically valid EWS for the communities living with landslide risks in CMA. This work is original and co-produced with the participation of stakeholders and the local population, contributing to a new model of EWS for mitigating landslide disasters in Bangladesh.

\section{Study Area Profile}

The selected case study area is administratively known as the Chittagong Metropolitan Area (CMA). CMA is the second largest urban-metropolis (after the capital city—Dhaka) in Bangladesh with a population of around 8 million. The Chittagong Development Authority (CDA) is the statutory planning authority of CMA and their jurisdiction area is approximately $680 \mathrm{~km}^{2}$. CMA is bounded on the southwest by the Karnafuli River, on the northeast by the Halda River, on the west by the Bay of Bengal and on the east by the Rangamati district (Figure 1). CMA lies between $22^{\circ} 06^{\prime}$ and $22^{\circ} 33^{\prime}$ north latitude and $91^{\circ} 41^{\prime}$ and $91^{\circ} 62^{\prime}$ east longitude. The annual average temperature of the Chittagong district varies from a maximum $32.5{ }^{\circ} \mathrm{C}$ to a minimum $13.5^{\circ} \mathrm{C}$, and the average annual rainfall is $3378 \mathrm{~mm}$ [34]. Chittagong had been a seaport since the ninth century [34] and is famous for its unique natural beauty characterized by hills, sea, rivers, valleys, and forests. The core-urbanized area of CMA is known as the Chittagong City Corporation (CCC) with an approximate area of $259 \mathrm{~km}^{2}$ (Figure 1b). The total population of CCC is approximately 2.6 million as per the 2011 population census (that was 1.3 million in 1991) with a density of 20,000 people per $\mathrm{km}^{2}$ [34]. 
The hills are less than 300 meters high, and often less than 100 meters. Unconsolidated Dupi Tila and Dihing sandstones and shales predominantly underlie them. The brown hill soils that cover most of the region include a wide range of soils developed over both hard and soft sandstones, siltstones, and shales. They mainly occur on steep slopes, especially in the high hills. Heavy rainfall-induced landslides and soil erosions are dominant on the hills [7,13,35]. Given its geomorphological, geological, and climatic characteristics, and human interventions such as hill cutting and deforestation, CMA has become highly vulnerable to landslides.

\section{Materials and Methods}

A total eleven landslide factors were identified (soil permeability, surface geology, landcover, altitude, slope, aspect; and distance to stream, fault line, hill cut, road cut, and drainage network) and a detailed landslide inventory map was prepared. Four statistical methods were applied to prepare the landslide susceptibility maps. After model validation, the map with the highest accuracy and spatial agreement was used for classifying the high, medium and low susceptible zones. A dynamic Web-GIS landslide EWS was developed by analyzing the rainfall thresholds, historical landslide events, and the susceptible zones. Finally, the EWS was presented to the vulnerable communities and concerned stakeholders in the CMA. They were trained on the efficiency, interpretation, dissemination and preparedness policy of the system at the local level.

\subsection{Preparing Landslide Factor Maps}

A detailed landslide inventory map was prepared by conducting fieldwork in 2014-2016, analyzing historical landslide events and local newspapers, and verifying the past landslide locations. A landslide investigation form was prepared to collect information on landslide location, size, volume, type, state, distribution pattern, style, rate, water content, material, land use type, cause of movement, and damage assessment through field surveys [9]. A landslide inventory of 52 landslide events in CMA was developed [36,37]. The daily rainfall data from 1960-2014 was collected from the Bangladesh Meteorological Department (BMD) and the data from 2015-2017 was obtained from the National Oceanic and Atmospheric Administration (NOAA)—National Centers for Environmental Information [38]. The CMA boundary, and drainage and road network layers were collected from the CDA. An ASTER digital elevation model (DEM) image (dated 29 November 2013) with a spatial resolution of $30 \mathrm{~m}$ was used to prepare the altitude, aspect, slope, and stream network maps. Landsat TM satellite images (dated 31 October 1990 and 23 November 2010, as the late autumn season is generally cloud free) were used to prepare the land cover maps [12,39]. A maximum likelihood supervised classification method was applied and six broad land cover types were identified. For validation purposes [40], local guide maps and Google Earth images (dated 31 December 1990 and 10 January 2011) were used. The details of the land cover mapping and accuracy assessment technique are described in [39]. The surface geology, soil permeability, and fault line map were collected from the GSB. The hill cut map was prepared by analyzing the land cover changes between 1990 and 2010 and through on-site validation. The distance maps were produced by applying the Euclidean distance technique. All the images $(30 \mathrm{~m} \times 30 \mathrm{~m})$ were set with the World Geodetic System (WGS)-1984 datum and Universal Transverse Mercator (UTM) 46 North projection system.

\subsection{Landslide Susceptibility Mapping}

A landslide susceptibility map (LSM) generally displays a quantitative/qualitative classification of areas that have the potential for the occurrence of landslides. In other words, susceptibility is related to spatial aspects of the hazard [41]. LSMs have been widely accepted and have become more popular with the advancement of geographic information system (GIS) and remote sensing (RS) tools and techniques, and availability of satellite images [42-44]. A variety of data-driven bivariate and multivariate statistical methods - the weights of evidence (WoE), logistic regression, and multiple linear regression (MR); machine learning methods-the random forest, artificial neural network (ANN), 
support vector machine (SVM); and user-defined weight based multi-criteria evaluation methods such as the analytic hierarchy process (AHP), weighted linear combination (WLC), and ordered weighted average (OWA), are being effectively implemented in the LSMs [10,12,45-47].

In this study, the ANN, SVM, MR, and a combination of MR and principal component analysis (PCA) methods were used. ANN is a reasoning model that was designed imitating human brain function and nervous system. Neural networks, with their remarkable ability to derive meaning from complicated data, can be used to extract patterns and detect trends that are too complex to be noticed by either humans or other computer techniques. A feed-forward multi-layer perceptron neural network that uses the back-propagation algorithm was employed. In this ANN model, a network of nodes is formed consisting of input layers, hidden layers, and output layers [39,47]. The input signal is processed layer by layer. If expected output result is not obtained, then the reverse propagation algorithm is run to adjust the network weights and thresholds for the desired output. The learning algorithm defines how network weights are adjusted between successive training cycles. After the network goal was reached, the whole study area was fed into the network to estimate the landslide susceptibility. For details please read [46-48].

The SVM is based on statistical learning theory and nonlinear transformations of covariates [49]. The SVM model is trained by a training dataset and a separate set of testing data is used to evaluate the results. Initially the SVM separates the data patterns using an optimum linear separating hyper-plane and later uses kernel functions to convert the original format that is separable in a high-dimension feature space [46]. The details of the SVM based LSM method is described in [47]. In MR [13], a least square approach was adopted to formulate a linear relationship between dependent (i.e., landslide locations) and independent variables (i.e., landslide causative factors). PCA was applied to produce a set of new images (also known as components) that were uncorrelated with one another and the first few components contain most of the information contained in the original dataset [13]. The combination of PCA and MR is labelled as PCA_MR.

The conditional independence (CI) tests for the eleven landslide factor maps were evaluated by applying the pair-wise Cramér's V [50] to understand the relationship between two dependent variables. The historical landslide locations were divided into training and testing datasets using a random sampling method. The training data was used to produce the LSMs and the testing dataset was used for model validation. The spatially agreed areas between the combinations of two LSMs were calculated to understand their overall performances [12]. The receiver operating characteristics (ROC) curves were used to validate the susceptibility maps [12,13]. It is a plot of the true positive rate (the cumulative percentages of observed landslides) against the false positive rate (the cumulative percentages of decreasing susceptibility index). The area under the ROC curve (AUC) value 0.5 means predictions are no better than random, whereas AUC with a value $>=0.9$ represents ideal situation [13].

\subsection{Rainfall Threshold Analysis}

Rainfall thresholds can be defined mainly by process-based/physical or empirical models. Physical models are dependent on detailed spatial information on various hydrological, morphological, lithological, and soil properties. However, acquiring such information requires extensive specialized field tests and continuous monitoring [51]. Empirical rainfall thresholds are defined by analyzing the rainfall-induced landslide events, in general, by Cartesian plotting [21]. The threshold is often measured by considering the antecedent conditions or precipitation measurements obtained for a specific rainfall event [52]. It is advantageous to define a localized rainfall threshold for initiating landslides. The available daily rainfall datasets collected from the BMD and NOAA were analyzed for historical rainfall analysis. Total rainfall for seven days prior to landslide events were considered. This technique has previously been applied to generate accurate results in the local context $[13,33]$. The 'RClimDex' statistical software package [53] was used for analyzing rainfall patterns. 


\subsection{The Framework for the Landslide EWS}

To understand how the landslide susceptibility index values are related to varying rainfall amounts, a hypothetical example is given in this section. Let us assume that a sequent of the study area is represented by a $6 \times 6$ cell square, as shown in Figure 2 (top part). It has been classified into no, low, medium, and high susceptible zones, respectively (see Figure 2, bottom part) by applying certain quantitative LSM methods. No susceptible zone (mostly covers waterbodies, floodplains, low lands, and sandy beach etc.) means it will never receive a warning for landslides under any circumstances, or any amount of rainfall.

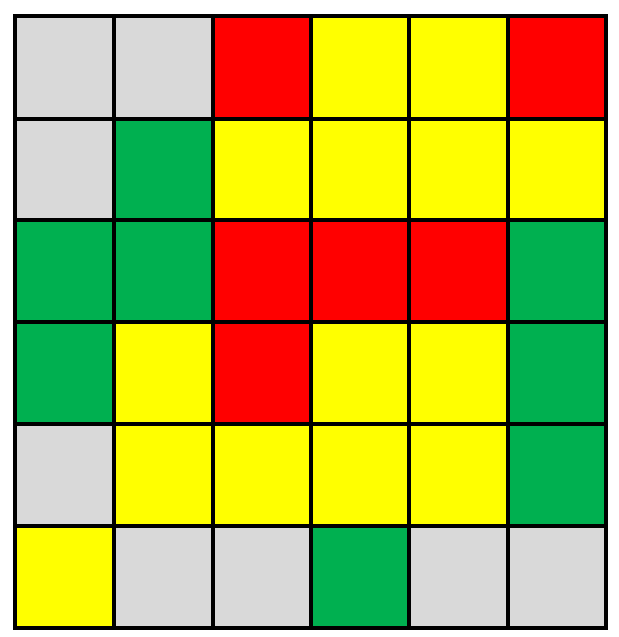

\begin{tabular}{|c|c|c|c|c|}
\hline LSM Zoning & No & Low & Medium & High \\
\hline Zoning ID & 1 & 2 & 3 & 4 \\
\hline
\end{tabular}

Figure 2. Association between (cell-based) landslide susceptibility index values and landslide warning zoning (imaginary) that are included in landslide susceptibility maps (LSMs).

Let us assume again, the rainfall pattern analysis has identified three rainfall rates $(\mathrm{R} 1=$ low rainfall, $\mathrm{R} 2$ = medium rainfall, and $\mathrm{R} 3$ = high rainfall). Next, a purposely-built landslide hazard matrix [54] is proposed (Figure 3) that assumes-the higher the susceptibility, the lower the rainfall level that could trigger landslides [23,55]. The hazard matrix corresponds between different rainfall rates and susceptibility classes, and produces two levels of qualitative hazard classes (i.e., no-warning state, and warning state).

Figure 4 illustrates the spatial distribution of landslide warning zones by simulating a simplified warning and no-warning situation. It helps to understand which zone needs a warning with respect to a certain amount of forecasted rainfall. For example, the low rainfall (forecasted) can trigger landslides in the high susceptible zone, this has been termed as scenario 1 (Figure 4a). If it rains within the medium threshold range (forecasted), then combined zones 4 and 3 will get a warning (Figure $4 \mathrm{~b}$ ), while zones 4, 3 and 2 together will be warned (Figure 4c) for the cases of high rainfall (forecasted). This means more areas/cells are likely to be affected or to receive an early warning if a higher amount of rainfall is expected. A back-analysis of the whole landslides dataset was used to validate the results. This kind of hazard matrix is easy to understand by the end users and policy makers, and has already been successfully applied by $[23,55,56]$. 


\begin{tabular}{|c|c|c|c|}
\hline $\begin{array}{c}\text { Landslide } \\
\text { Hazard Matrix }\end{array}$ & $\begin{array}{c}\text { Zone 2 } \\
\text { (Low LSM) }\end{array}$ & $\begin{array}{c}\text { Zone 3 } \\
\text { (Medium LSM) }\end{array}$ & $\begin{array}{c}\text { Zone 4 } \\
\text { (High LSM) }\end{array}$ \\
\hline $\begin{array}{c}\text { R1 } \\
\text { (Low Rainfall) }\end{array}$ & & \\
\hline $\begin{array}{c}\text { R2 } \\
\text { (Medium Rainfall) }\end{array}$ & & \\
\hline $\begin{array}{c}\text { R3 } \\
\text { (High Rainfall) }\end{array}$ & & \\
\hline
\end{tabular}

Figure 3. The proposed hazard matrix showing the combination of rainfall rates and susceptibility classes.

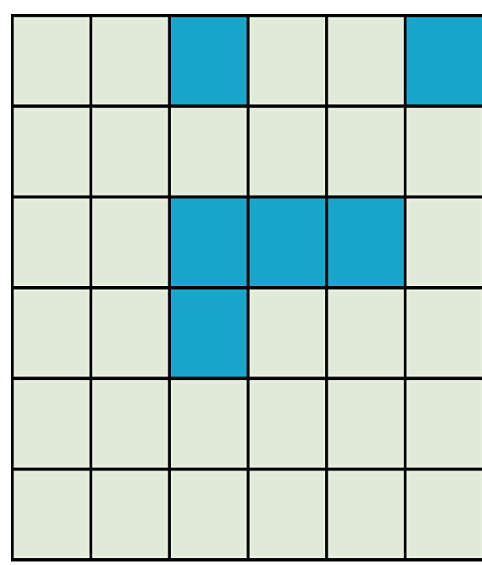

(a) Scenario 1: Low Rainfall (R1) [Zone 4$]=6$ cells affected

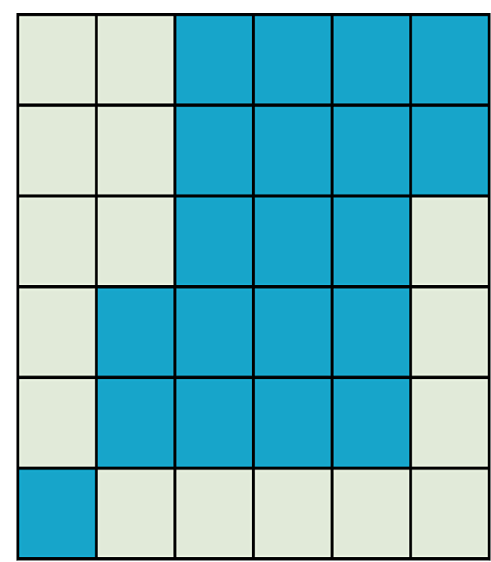

(b) Scenario 2: Medium Rainfall (R2) [Zones 4+3] $=20$ cells affected

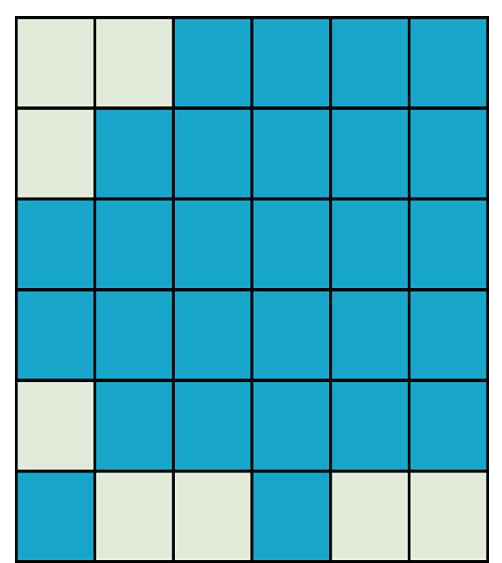

(c) Scenario 3: High Rainfall (R3) [Zones $4+3+2]=28$ cells affected

Figure 4. An example of how landslide warning zoning changes due to variations in total (forecasted) rainfall within a particular time period.

\subsection{The Landslide Web-Warning System Development}

In the next step, a website was designed for developing the landslide alert system. The EWS displays different susceptible zones according to precipitation. The precipitation data is being collected from www.worldweatheronline.com scheduled twice a day as it provides publicly available APIs. The tools have been leveraged with various libraries and frameworks, for instance, Python 2.7 (Python Software Foundation, Delaware, USA) along with GDAL, a Geospatial Data Abstraction Library, is used to process and reclassify raster dataset; MySQL (Oracle Corporation, California, USA) for database; whereas PHP (Zend Technologies, California, USA) as a server-side language. Several JavaScript APIs are used for client-side interface and interaction namely OpenLayers for displaying map data in web browsers, W2UI JavaScript UI library for layouting, and jQuery along HTML5 and CSS. Before deploying the EWS online, the system needs to process a classified raster dataset (.tiff) of the study area. The classified TIF folder contains several files: .tif, .tif.aux, .tif.rrd/.tif.ovr, tif.vat.dbf. Basically, statistical information for the raster dataset is stored in a separated auxiliary file (.tif.aux.xml), and it stores a pointer to the pyramid file (, .tif.rrd/.tif.ovr) and the attribute table is stored in another file (tif.vat.dbf).

The classified tiff may contain continuous values having a range of $0-1$ or in some contexts it may be reclassified as discrete number, say, $0,1,2,3,4,5$ etc., otherwise the continuous values have 
to be reclassified into discrete ones (0-5). A RasterPack python module has been developed to generate this new format. The very first line of the text file is meta data of the raster file, for example, MinX, MaxY, Rows, Cols, CellSize, MaxX,MinY, SemiMajorAxis, InverseFlattening, LatitudeOfOrigin, CentralMeridian, ScaleFactor, FalseEasting, and FalseNorthing for further projection of landslide zoning map while overlaying in the Open Street Map. Using PHP, a special raster format was created from the text file to speed up the display of the susceptible zones in different colors, and resampling is made if image size is big enough to render in web browsers in terms of memory and loading time. The precipitation is stored in a MySQL database. In the EWS, users can register themselves through subscription to different types of alerts. The flowchart of the landslide EWS development process is illustrated in Figure 5.

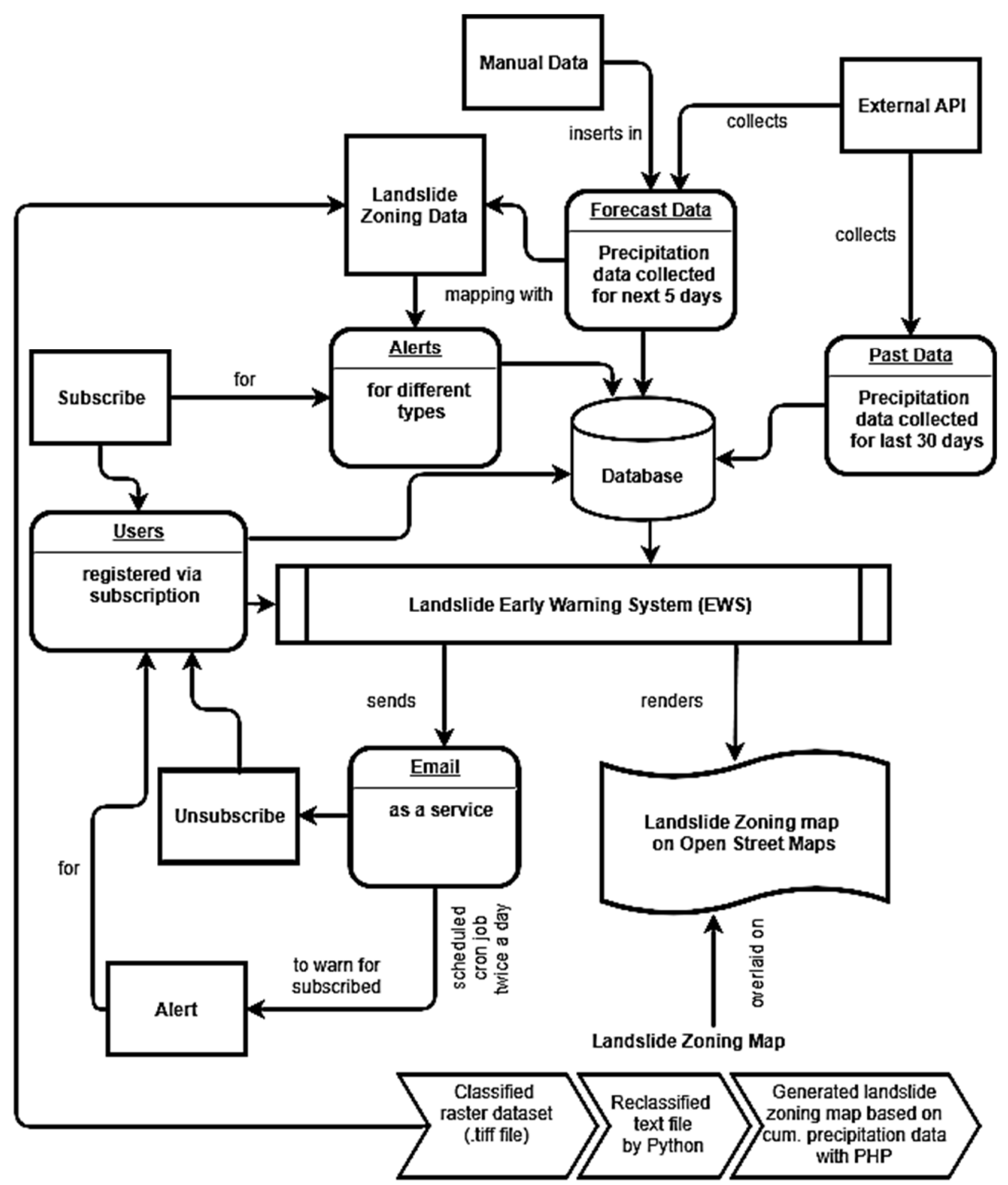

Symbols

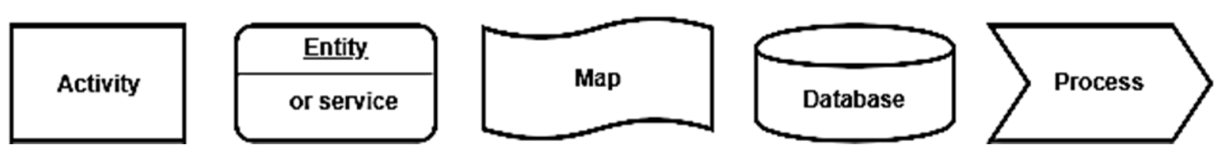

Figure 5. A schematic diagram showing the system architecture for the Web-GIS based landslide early warning. 
The link insert.php is a proxy to collect rainfall data daily through the external API of worldweatheronline.com in the background. It is scheduled in a cron job in the Linux server. It sends email alerts to the registered users depending on the specified cumulative precipitation and it displays live on www.landslidebd.com/map-ctg/. Images of the raster dataset are generated dynamically using PHP on demand using the reclassified text file which is generated by the RasterPack Python module. In order to update the system, it is just required to upload a newer version of the reclassified image as shown in Figure 6. The system can store rainfall values for previous 30 days and has a provision to enter ten days advanced precipitation values manually from another source. It is useful for generating various warning scenarios, and thus for validating the system-generated results. The end users (residents or stakeholders) can register themselves on the website and receive landslide alerts via email notifications five days in advance for their respective zones.

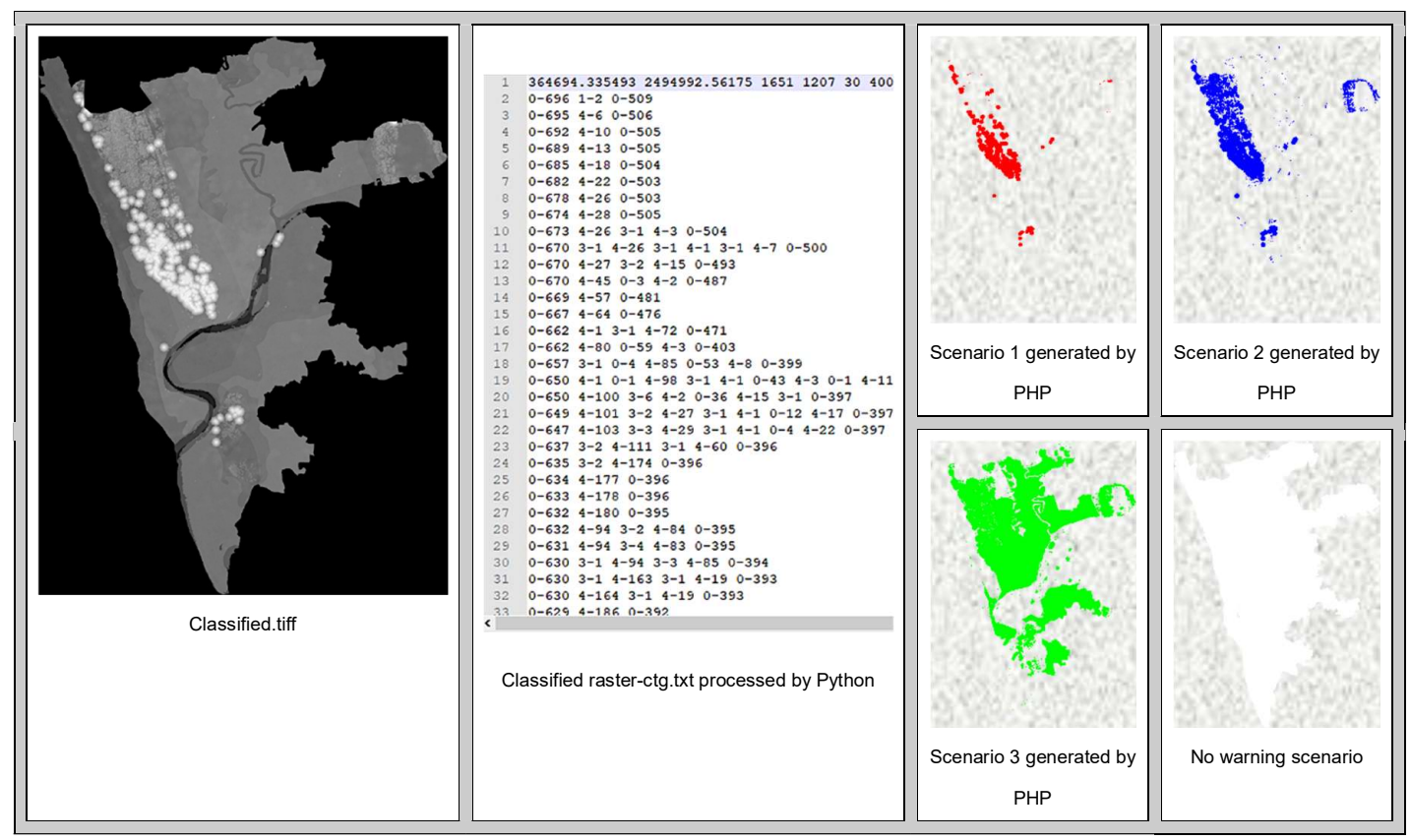

Figure 6. Reclassified text file from the classified tiff file.

\subsection{Dissemination of Landslide Warnings}

To understand the overall landslide disaster scenario, a series of workshops and meetings were conducted with various government officials, community representatives, and local people. The intention was to create a platform to introduce the landslide EWS to these groups and implement it in the real-world to help mitigate the landslide disaster impacts in the CMA.

\section{Results}

\subsection{Landslide Factor Maps}

The eleven landslide factor maps are displayed in Figure 7. Soil permeability was divided into mixed-moderate, moderate, rapid, slow, and very slow categories (Figure 7a) as defined by the Soil Resource Development Institute (SRDI), Bangladesh. The geology map (Figure $7 \mathrm{~b}$, for a detailed map please see the Appendix A, Figure A1) was classified as beach sand, Boka Bil, Tipam, Sandstone, Dupi Tila, Valley, and Dhing. Boka Bil, Tipam, Dupi Tila, and Dhing formations are actually hilly deposits from the Tertiary period. Beach sand and Valley formations are from the Quaternary period. Beach sand/tidal deposits are formed near the coast due to tidal actions and are dominated by silt or silt and clay. Valley deposits are formed due to erosional activities near the hilly region and are composed of sand, sandy clay, and silty clay $[12,13,35]$. The land cover map was prepared using six 
broad classes: built-up areas; cropland; waterbodies; hill forest; bare soil; and shrub land (Figure 7c). The overall accuracy of the land cover map was found to be $86 \%$, using error-matrix based accuracy assessment [39]. The aspect map contains the conventional eight directions (Figure 7g). The landslide locations were randomly divided into two groups: testing and training landslides (Figure 7l).

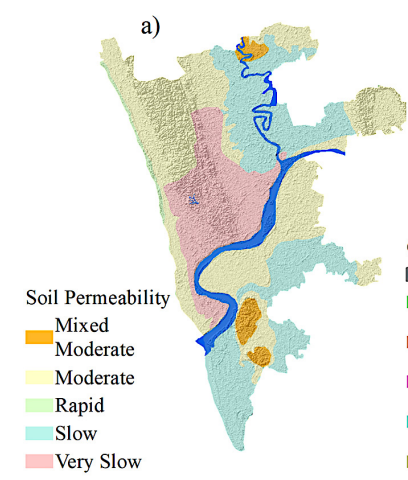

e)

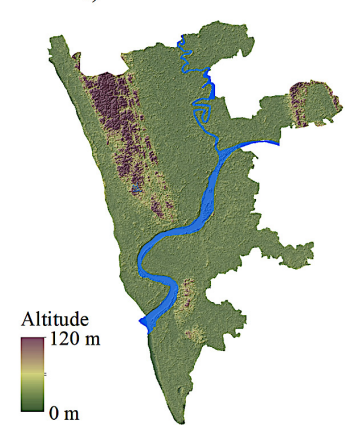

i)

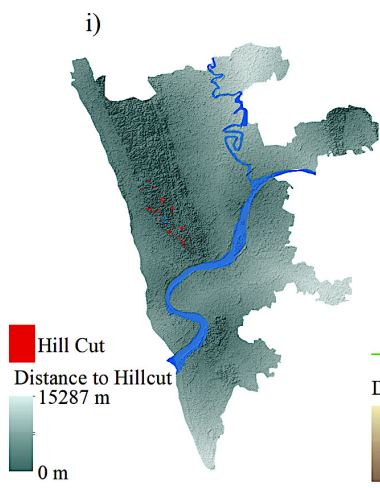

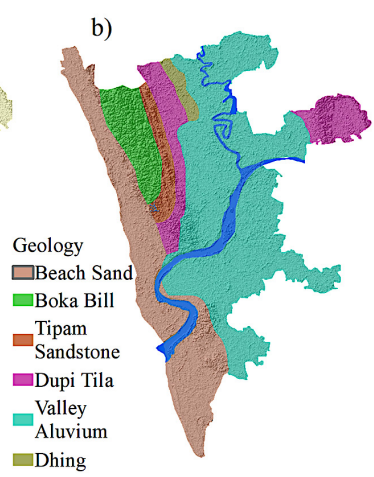
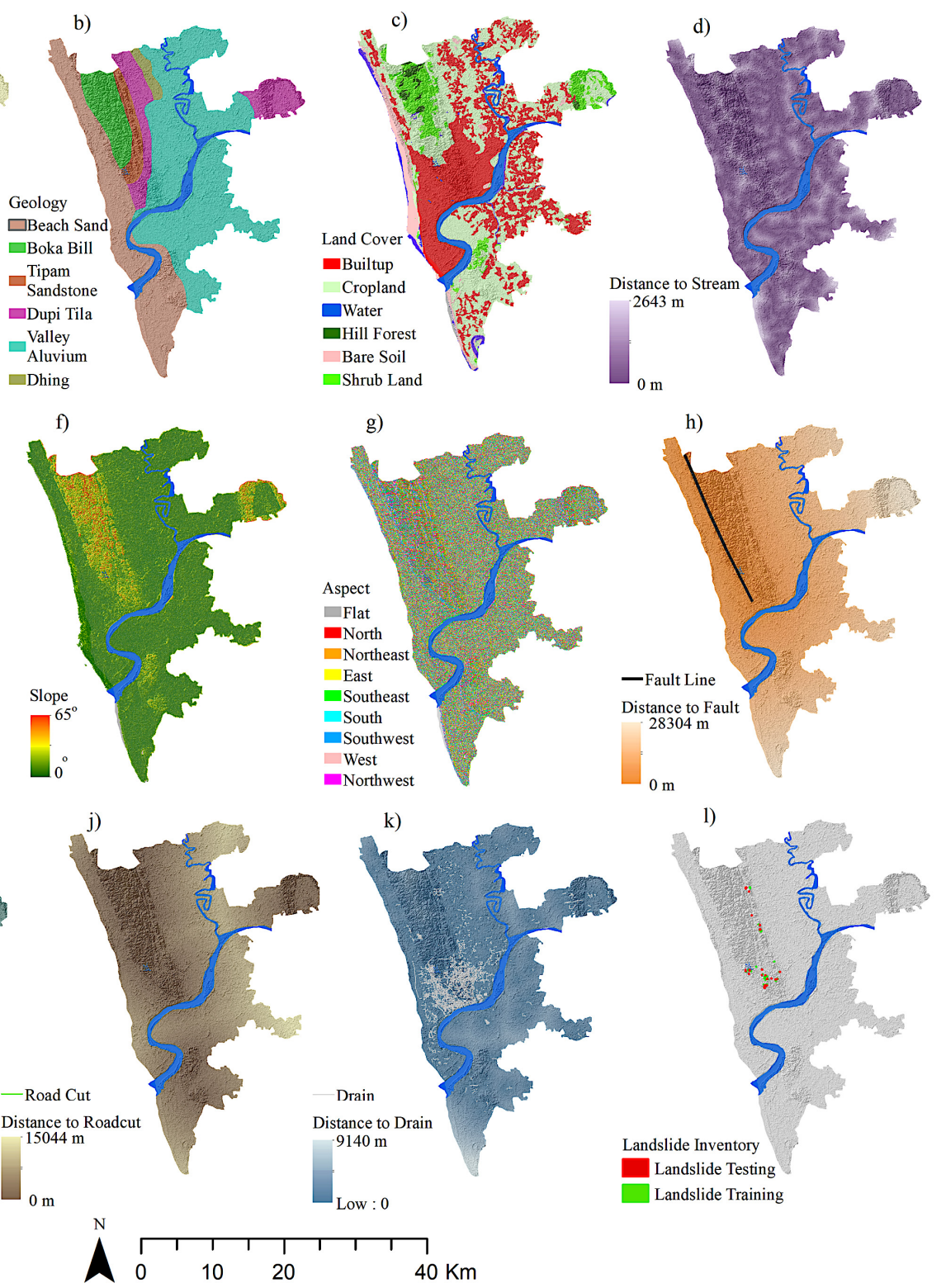

Landslide Testin Landslide Training

$40 \mathrm{Km}$

Figure 7. Landslide factor maps: (a) soil permeability; (b) surface geology; (c) landcover; (d) distance to stream; (e) altitude; (f) slope; (g) aspect; and distance to (h) fault line; (i) hill cut; (j) road cut;

(k) drainage network; and (1) landslide inventory map.

\subsection{Landslide Susceptibility Mapping and Model Selection}

The eleven landslide factor maps and the landslide training datasets were used to produce the ANN, SVM, MR, and PCA_MR susceptibility maps (Figure 8). The prediction capability of the LSMs are different and they vary spatially. 

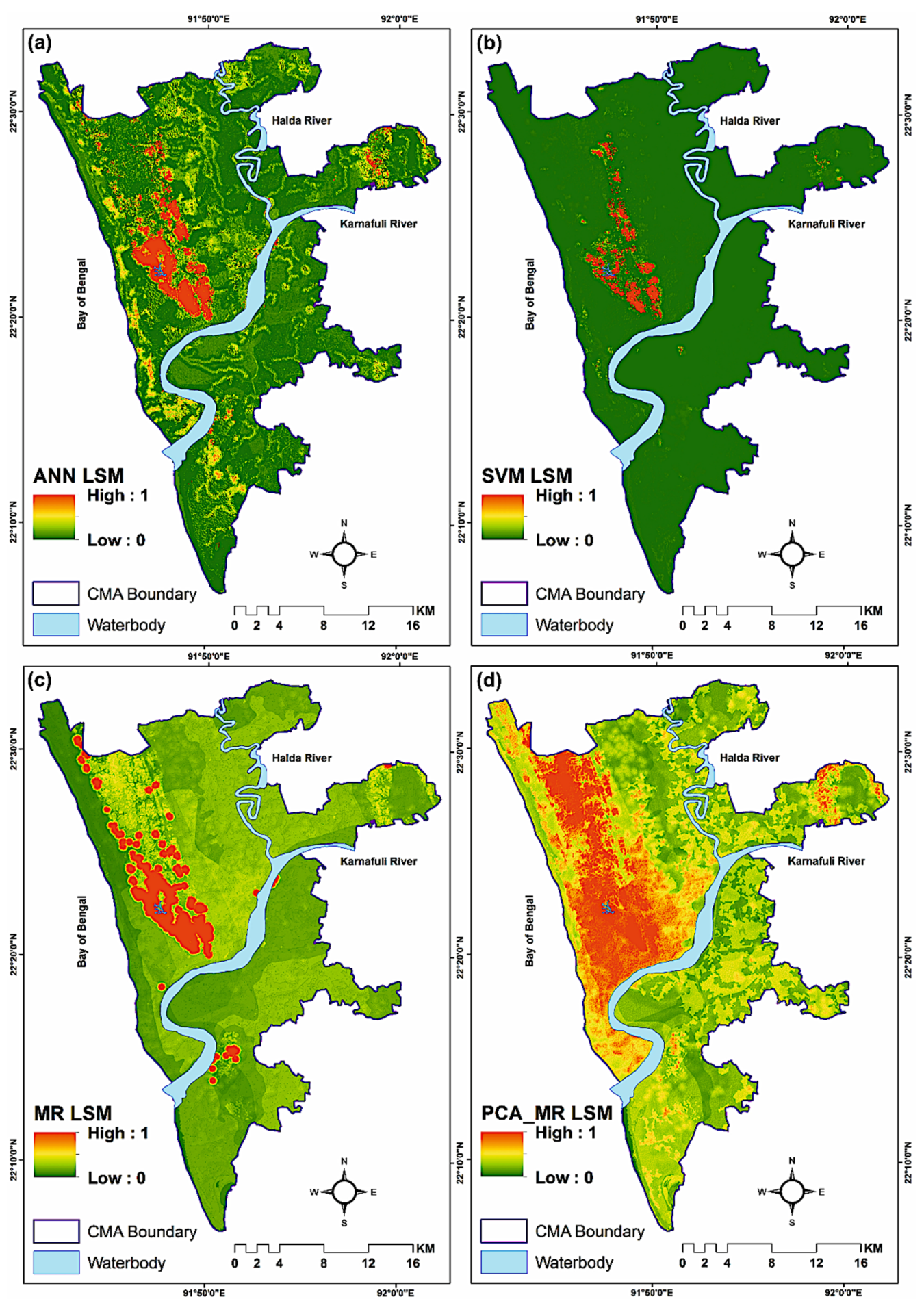

Figure 8. Landslide susceptibility maps found by applying (a) artificial neural network; (b) support vector machine; (c) multiple linear regression (MR); and (d) principal component analysis (PCA) and MR methods.

The ROC method was applied to select the best fit model. The AUC success rate values for the ANN, SVM, MR, and MR_PCA models were calculated 97.71\%, 96.11\%, 99.47\%, and 93.35\%, respectively (Figure 9). The selection of the best model also relates to consistency analysis of the models. The ROC curves help to understand the statistical consistency and scientific validity of the models; however, it is also necessary to analyze the spatially agreed areas between two LSMs to understand the overall performance. In the case of SVM and ANN comparison, about $79 \%$ of areas 
fell into identical susceptible zones, $61 \%$ landslides fell in high susceptibility zone, and total agreed landslide areas were calculated to be $65 \%$. For the SVM and MR comparison, values for the total area of agreement, landslides in high susceptibility zone, and total landslide agreed areas were found $50 \%$, $49 \%$, and $52 \%$; and for the ANN and MR comparison, the same values were calculated $50 \%, 54 \%$, and 58\%, respectively (see Appendix A, Table A2). The general assumption is that the LSM with the best combination of the highest AUC value, the highest percentage of spatially agreed areas and the highest landslide density in the high susceptibility zone should be selected for further analysis $[12,57]$. Henceforth, the ANN LSM was found to be the best fit model for CMA and was selected for developing the landslide EWS.
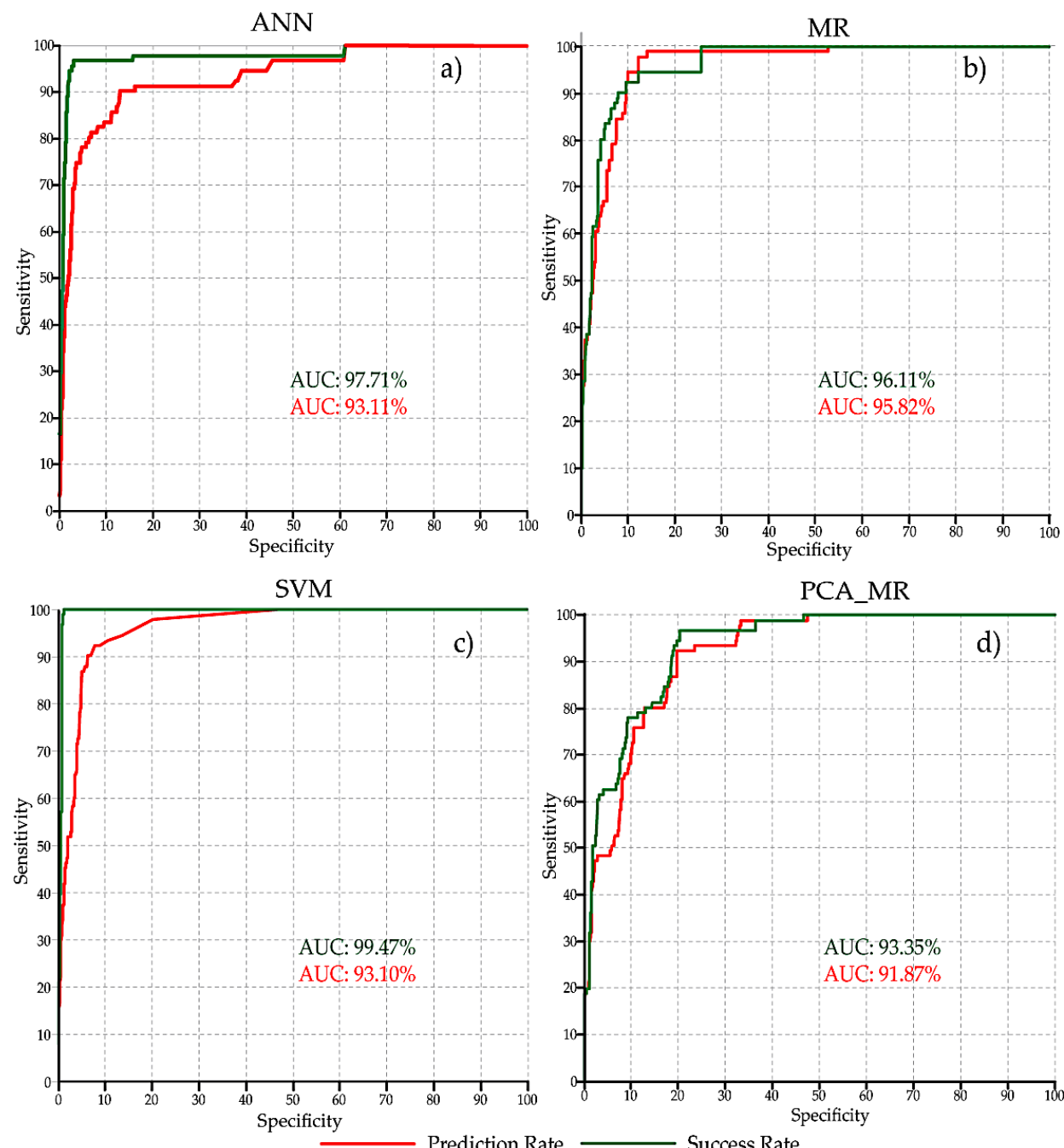

Figure 9. Receiver operating characteristics (ROC) curves and area under the ROC curve (AUC) values for the (a) ANN; (b) MR; (c) SVM; and (d) PCA_MR landslide susceptibility maps.

\subsection{Rainfall Threshold Analysis Results}

Historical daily rainfall data (1950-2013) for the Chittagong district were analyzed to understand the local rainfall pattern. The results show that the average annual rainfall was around $3000 \mathrm{~mm}$ and about $95 \%$ of the total rainfall occurred within the months of May to September. On average, the monthly precipitation varied from $400-500 \mathrm{~mm}$ from June to September. During the monsoon season, around 15 consecutive days of precipitation (30 days in extreme case), 41 days of rainfall over $20 \mathrm{~mm}$, and heavy rainfall ( $\geq 50 \mathrm{~mm}$ ) for a total of 18 days was observed in CMA. Just to clarify Table 1 , the first indicator (monthly maximum 1-day precipitation) suggests that the maximum 1-day rain for each month (mostly covers the monsoon season) ranges from 115 to $511 \mathrm{~mm}$, with an average value of 
$236 \mathrm{~mm}$. The monthly maximum five-consecutive days of precipitation (average) in the monsoon was calculated to be $490 \mathrm{~mm}$ (Table 1 ).

Table 1. Rainfall pattern analysis results.

\begin{tabular}{|c|c|c|c|c|}
\hline Indicator Description & $\begin{array}{l}\text { Precipitation } \\
\text { Index (Unit) }\end{array}$ & Minimum & Maximum & Average \\
\hline \multirow{2}{*}{$\begin{array}{l}\text { Monthly maximum 1-day precipitation } \\
\text { Monthly maximum consecutive 5-day } \\
\text { precipitation }\end{array}$} & $\mathrm{R} \times 1(\mathrm{~mm})$ & 115 & 511 & 236 \\
\hline & $\mathrm{R} \times 5(\mathrm{~mm})$ & 208 & 1037 & 490 \\
\hline Annual count of days when PRCP $>=10 \mathrm{~mm}$ & R10 (days) & 41 & 80 & 61 \\
\hline Annual count of days when PRCP $>=20 \mathrm{~mm}$ & R20 (days) & 27 & 60 & 41 \\
\hline \multirow{3}{*}{$\begin{array}{l}\text { Annual count of days when PRCP }>=n n \mathrm{~mm} ; \mathrm{nn} \\
\text { is user defined threshold }\end{array}$} & R50 (days) & 8 & 30 & 18 \\
\hline & R75 (days) & 4 & 18 & 10 \\
\hline & R100 (days) & 1 & 14 & 6 \\
\hline $\begin{array}{l}\text { Maximum number of consecutive days with } \\
\qquad \text { PRCP }>=1 \mathrm{~mm}\end{array}$ & CWD (days) & 7 & 30 & 15 \\
\hline Annual total PRCP in wet days (PRCP $>=1 \mathrm{~mm}$ ) & $\begin{array}{l}\text { PRCPTOT } \\
\quad(\mathrm{mm})\end{array}$ & 1780 & 4340 & 2917 \\
\hline
\end{tabular}

For estimating the rainfall threshold, the major historical landslide events (see Appendix A, Table A1) and associated rainfall data were analyzed. This study has considered rainfall on the day of landslide and up to seven days before the event by plotting the values in the Cartesian graph for simple statistical analysis to define the rainfall thresholds. The results reveal that landslides are mostly associated with rainfall up to 4 days prior to the event (Figure 10, and Table 2).

As per the rainfall trend analysis (Figure 10, and Table 2), a landslide warning can be issued at least five days in advance if the cumulative rainfall is predicted to be $71-288 \mathrm{~mm}$ or above. It is found (considering median values only) that $71 \mathrm{~mm}$ rainfall in $24 \mathrm{~h}$, or $148 \mathrm{~mm}$ rainfall in $48 \mathrm{~h}$, or $211 \mathrm{~mm}$ rainfall in $72 \mathrm{~h}$ could trigger a landslide (Table 2).

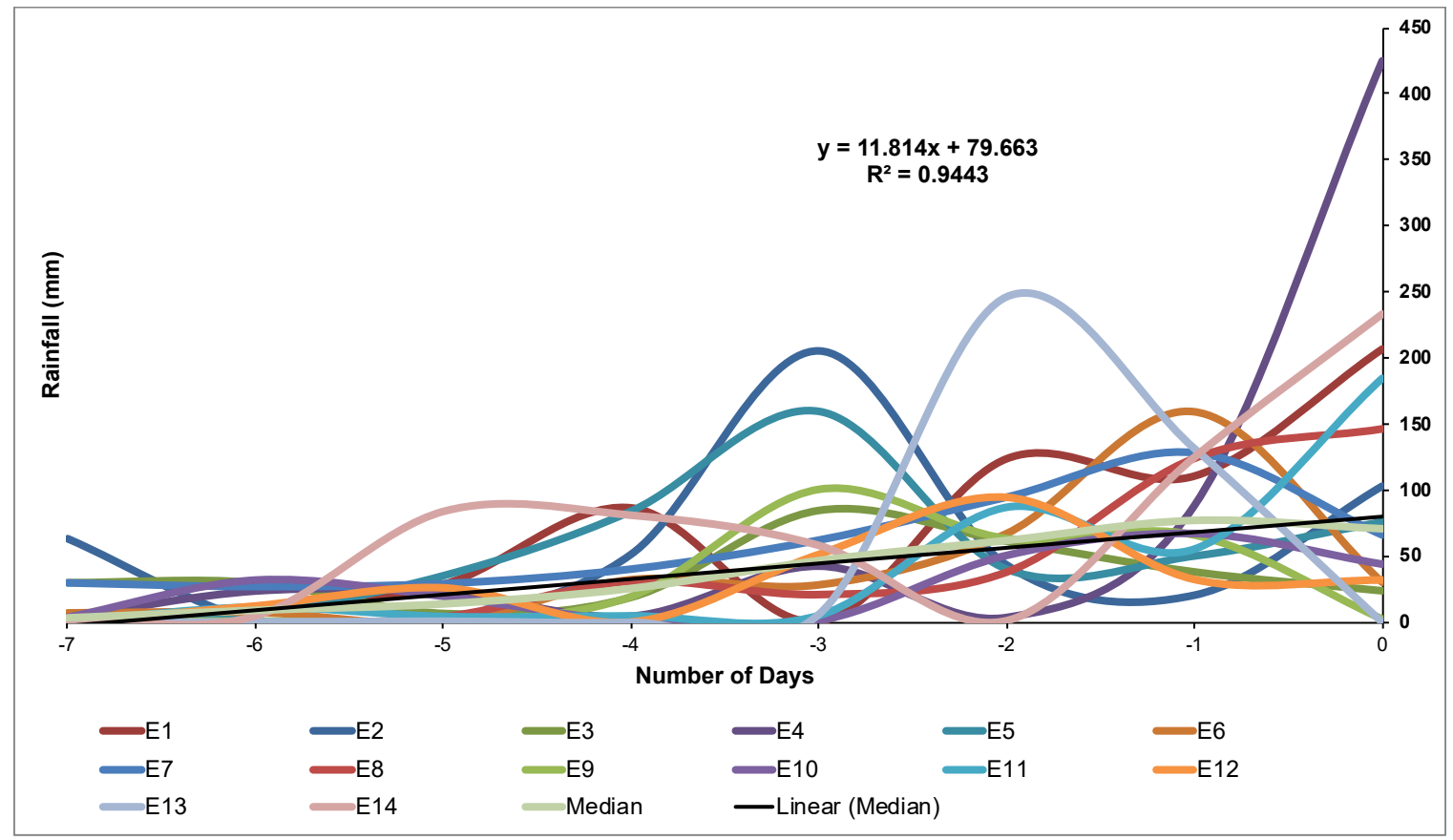

Figure 10. Rainfall trend analysis for triggering landslides in Chittagong Metropolitan Area. Here, "E" stands for landslide event number (see Table 2); "0" refers to the day of the landslide event; and " -7 " refers to seven days before the landslide event. 
Table 2. Calculations showing rainfall thresholds for different days from the landslide events.

\begin{tabular}{cccccccccc}
\hline \multirow{2}{*}{ Event ID } & \multirow{2}{*}{ Event Date } & \multicolumn{6}{c}{ Number of Days Prior to and on the Day of the Major Landslide Events } \\
\cline { 3 - 10 } & & $-\mathbf{7}$ & $\mathbf{- 6}$ & $\mathbf{- 5}$ & $\mathbf{- 4}$ & $\mathbf{- 3}$ & $\mathbf{- 2}$ & $\mathbf{- 1}$ & $\mathbf{0}$ \\
\hline E1 & $\mathbf{1 3 / 0 8 / 1 9 9 9}$ & 5 & 9 & 28 & 86 & 0 & 123 & 110 & 206 \\
E2 & $\mathbf{2 9 / 0 6 / 2 0 0 3}$ & 63 & 1 & 2 & 51 & 206 & 43 & 20 & 103 \\
E3 & $\mathbf{1 0 / 0 7 / 2 0 0 6}$ & 30 & 30 & 7 & 19 & 84 & 61 & 38 & 24 \\
E4 & $\mathbf{1 1 / 0 6 / 2 0 0 7}$ & 3 & 23 & 22 & 4 & 42 & 3 & 88 & 425 \\
E5 & $\mathbf{1 0} 09 / 2007$ & 0 & 7 & 35 & 84 & 160 & 40 & 50 & 76 \\
E6 & $\mathbf{1 8 / 0 8 / 2 0 0 8}$ & 7.2 & 7.8 & 0.2 & 32.4 & 28.5 & 67.4 & 159.5 & 30.4 \\
E7 & $\mathbf{0 1 / 0 7 / 2 0 1 1}$ & 30 & 27.2 & 29.5 & 40.4 & 62.2 & 94.5 & 127.8 & 66 \\
E8 & $\mathbf{2 6 / 0 6 / 2 0 1 2}$ & 1 & 0 & 4.3 & 31.2 & 21.1 & 38.1 & 124.2 & 146.3 \\
E9 & $\mathbf{2 8 / 0 7 / 2 0 1 3}$ & 0 & 0.5 & 0 & 19.1 & 100.6 & 63.2 & 65.8 & 2 \\
E10 & $\mathbf{2 1 / 0 6 / 2 0 1 4}$ & 3.8 & 31.8 & 19.6 & 1 & 1.3 & 50.5 & 66.8 & 43.9 \\
E11 & $\mathbf{2 3 / 0 6 / 2 0 1 5}$ & 0 & 11.4 & 4.3 & 4.8 & 5.1 & 86.6 & 55.1 & 183.9 \\
E12 & $\mathbf{1 9 / 0 7 / 2 0 1 5}$ & 0 & 12.2 & 25.9 & 0 & 51.3 & 94.5 & 32.3 & 31.8 \\
E13 & $\mathbf{1 3 / 0 6 / 2 0 1 7}$ & 0 & 0.3 & 0.8 & 0 & 6.1 & 246.4 & 131.6 & 0 \\
E14 & $\mathbf{2 1 / 0 7 / 2 0 1 7}$ & 2 & 5.1 & 84.1 & 81.3 & 58.4 & 1.5 & 125.2 & 233.4 \\
& Mean & 10.36 & 11.88 & 18.76 & 32.44 & 59.04 & 72.34 & 85.31 & 112.26 \\
& Median & $\mathbf{2 . 5 0}$ & $\mathbf{8 . 4 0}$ & $\mathbf{1 3 . 3 0}$ & $\mathbf{2 5 . 1 5}$ & $\mathbf{4 6 . 6 5}$ & $\mathbf{6 2 . 1 0}$ & $\mathbf{7 7 . 4 0}$ & $\mathbf{7 1 . 0 0}$ \\
\hline
\end{tabular}

Here, " 0 " refers to the day of the landslide event, and " -7 " refers to seven days before the landslide event.

In this work, 5-days consecutive rainfall was considered for rainfall threshold analysis, as around $95 \%$ of the median values fitted the model (i.e., coefficient of determinants, $\mathrm{R}^{2}=0.9475$ ). The rainfall threshold for triggering landslides was estimated ranging from 70-250 mm, which is a conservative method and helps to avoid any unavoidable errors. Next, the threshold range was classified into three rates using the equal-interval method: low rainfall (70-160 mm), medium rainfall (161-250 mm), and high rainfall $(>250 \mathrm{~mm})$. The susceptible zones with the varying amounts of rainfall that is considered to triggering landslides is connected by applying the hazard matrix as shown in Figure 3. A total of 36 landslides (as some inventories were missing relevant information) were used to validate the approach. As per the matrix assumption, the least number of landslides will occur in low rainfall/low susceptibility (R1/S1) zone, and the majority of landslides will occur in high rainfall/high susceptibility zone (R3/S3). The results show that no landslide was reported in zones R1/S1, R1/S2, and R2/S1 (Table 3). Around 66\%, and 72\% landslides occurred in high rainfall, and high susceptibility zones, respectively. Most landslides (50\%) were observed in zone R3/S3 (Table 3). It proves that the method of combining various rainfall rates and susceptibility classes, as proposed in this work, is statistically valid and applicable for the CMA.

Table 3. Number of landslides occurred in different combinations between rainfall rates and susceptibility classes.

\begin{tabular}{ccccc}
\hline Validation Matrix & $\begin{array}{c}\text { S1 = Zone 2 } \\
\text { (Low LSM) }\end{array}$ & $\begin{array}{c}\text { S2 = Zone 3 } \\
\text { (Medium LSM) }\end{array}$ & $\begin{array}{c}\text { S3 = Zone 4 } \\
\text { (High LSM) }\end{array}$ & $\begin{array}{c}\text { Total } \\
\text { Landslides (\%) }\end{array}$ \\
\hline $\begin{array}{c}\text { R1 } \\
\text { (Low Rainfall) }\end{array}$ & 0 & 0 & 2 & $2(6 \%)$ \\
$\begin{array}{c}\text { R2 } \\
\text { (Medium Rainfall) } \\
\text { R3 }\end{array}$ & 0 & 4 & 6 & $10(28 \%)$ \\
$\begin{array}{c}\text { (High Rainfall) } \\
\text { Total Landslides (\%) }\end{array}$ & $2(6 \%)$ & $8(22 \%)$ & $26(72 \%)$ & $36(100 \%)$ \\
\hline
\end{tabular}

\subsection{Developing the Landslide Web-Warning System}

The ANN LSM was classified into four zones: high; medium; low; and never warning (Figure 11a). The natural break classification was used as it represents the natural groupings inherent in the data [39]. The landslide warning zones and their subsequent rainfall rates with zone delineations are depicted in 
Table 4, and Figure A2 (see Appendix A). The ANN LSM with cell values ranging from 0-0.071 will never get any landslide warning (cross-verified by Table 3 ). The high warning zone with cell values 0.592-1 will get warnings if the 5-day cumulative rainfall is forecasted to be $70-160 \mathrm{~mm}$ (Figure 11b). If 161-250 mm rain is expected during five consecutive days, the ANN LSM index values of $0.263-1$ will get landslide warnings (Figure 11c).
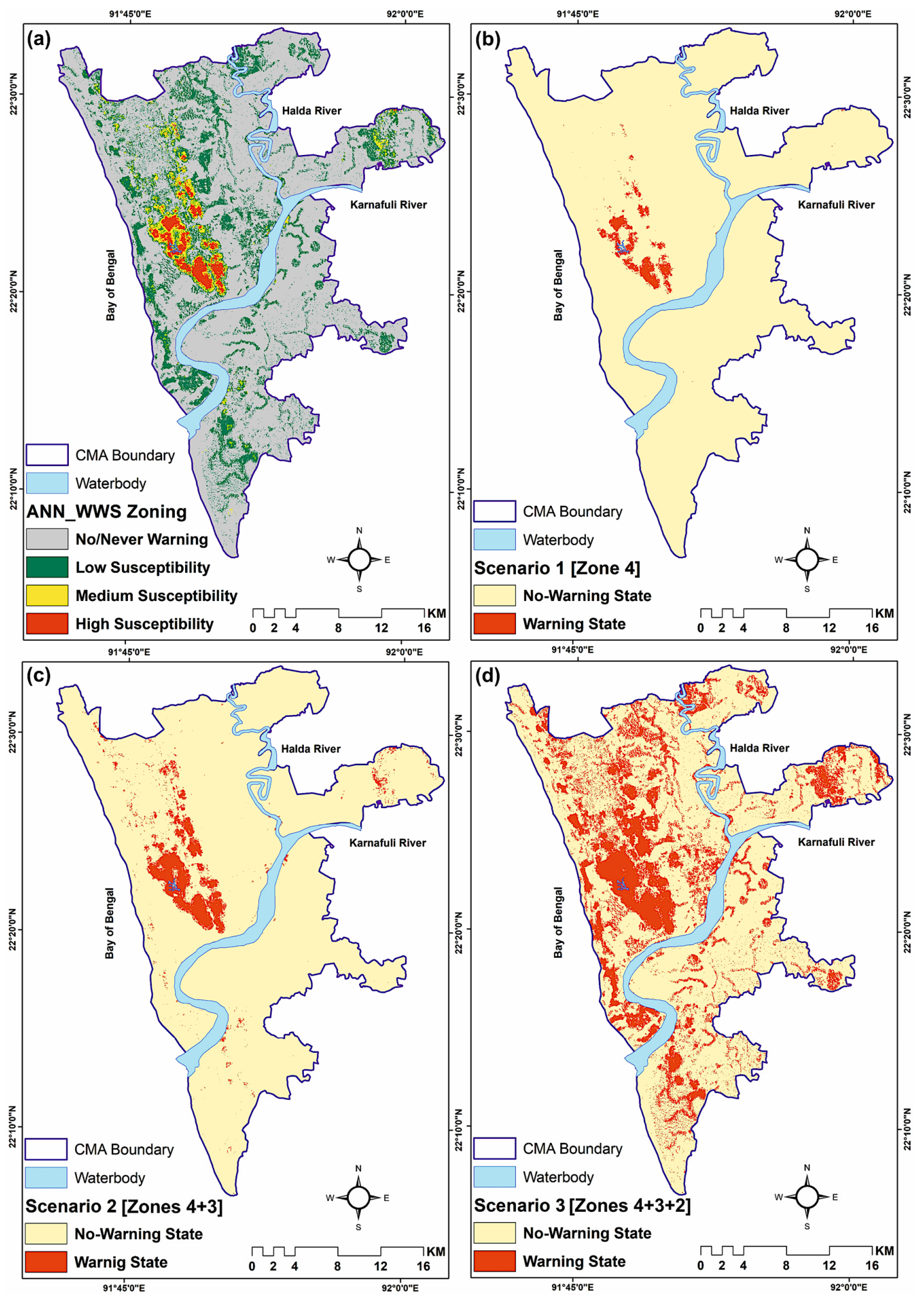

Figure 11. (a) Landslide warning classification from the ANN LSM and the spatial distribution of landslide warnings for various scenarios. 
Table 4. Rainfall thresholds for landslides and their association with susceptibility zones.

\begin{tabular}{ccc}
\hline $\begin{array}{c}\text { Rainfall Amount (mm) } \\
\text { [Consecutive 5 Days Cumulative] }\end{array}$ & LSM Index Values & $\begin{array}{c}\text { Zone and Scenario } \\
\text { Delineation }\end{array}$ \\
\hline Low Rainfall (R1) $=70-160$ & $0.592-1$ & Zone 4 [Scenario 1] \\
Medium Rainfall (R2) $=161-250$ & $0.263-1$ & Zones 4+3 [Scenario 2] \\
High Rainfall (R3) $>250$ & $0.071-1$ & Zones 4+3+2 [Scenario 3] \\
Never Warning & $0-0.071$ & Zone 1 \\
\hline
\end{tabular}

In the next step, the ANN LSM with warning classifications was converted to fit into a Web alert system as described in Section 3.5. The proposed landslide EWS (http:/ / www.landslidebd.com/ ctg-warning-system/) is connected with a reliable online-based weather application programming interface (https: / / developer.worldweatheronline.com/api/). The reliability of the warning results was validated using the case of a recent landslide event (see Appendix A, Table A1). The landslide was triggered by heavy rainfall ( $464 \mathrm{~mm}$ in 5 days) on the 14 October 2018 and killed four people in CMA (as per our LSM classification the areas belong to high susceptible zone). The landslide warnings were successfully generated from the newly developed EWS and disseminated via email notifications four days beforehand the disaster event (see Appendix A, Figure A3). It proves the reliability of rainfall threshold analyses and their appropriateness in forecasting accurate warnings.

\subsection{Community Training and Stakeholder Engagement}

The project team members arranged some activities (see Appendix A, Figure A4) in CMA to create public awareness, train the local people and connect the stakeholders. A national seminar (Figure A4a) was held. Around 35 senior and mid-level officials/experts from different organizations related to landslide research, disaster emergency, and mitigation programs were present on this occasion. The key informants and officials were found to be well aware of the landslide situation in CHD. They were in full support of the implementation of the master plan, hill cutting regulations, and a landslide early warning system in CMA. They emphasized the need to build awareness among local communities and strengthen the existing hill management committee in Chittagong.

\section{Discussion and Future Research}

This work has several issues that need to be addressed in future research. First, a detailed historical landslide inventory map is missing. Only information for the major landslide events were collected from various secondary sources and were validated following fieldworks. Our survey team could only identify the locations where major consequences were reported like human casualties or houses and roads being damaged or destroyed. Locations of other minor landslide hazards (where no casualty or damage was reported, but the hill was physically damaged or partially collapsed) could not be incorporated in the analysis. This is a major drawback of this work. The CMA had no detailed landslide inventory, and hill cutting maps. This work has produced the first ever landslide inventory, hill cutting, and susceptibility maps for CMA using available resources. Even for the recent landslides, there is no monitoring system to survey the whole study area and identify landslide hit areas (with or without human habitation). The Government of Bangladesh (GoB) should immediately form a specialist team to conduct necessary surveying and prepare inventory maps after any landslide event.

Second, no rainfall intensity $(\mathrm{mm} / \mathrm{h})$ information is available from the Bangladesh Meteorological Department (BMD), who is solely responsible for collecting historical rainfall data in Bangladesh. Only daily rainfall data is available in a restrictive way. In 2015, the GSB installed two solar-powered automatic weather monitoring and rainfall prediction stations in Chittagong City, but they do not share the data publicly. This is another major limitation of this work, The proposed landslide EWS is based on analyzing daily rainfall data available from the only BMD station in Chittagong. BMD also does not provide any API services to connect forecasted precipitation data, so we have utilized a commercial external service that depends on data from the World Meteorological Organization. 
Third, we want to raise the issue of projection anomalies of different factor maps, and the availability of high-resolution satellite images, improved topographic data, and DEM. For example, some maps were available in Bangladesh Transverse Mercator (BTM) projections (the study area boundary, soil permeability, geology, road cutting, and fault map), and others were in UTM projections. The landslide inventory map was prepared using a handheld GPS device, and later the locations were plotted in Google Earth. Some layers were produced from low-resolution satellite images (landcover, hill cutting, slope, etc.). Although appropriate coordinate transformation techniques were applied in ArcGIS environment, it was a challenging task to ensure that all the factor maps overlapped (cell-by-cell) properly. As a result, still some errors may exist in the LSM analysis. To overcome such limitations, it requires coordination among different GoB organizations to produce a unified sets of landslide factor maps for Chittagong.

Hill cutting is a major concern for the case study area (Figure 12). The LSM maps should be regularly updated by incorporating the most updated landcover, hill cut, road cut, landslide inventory, and slope maps. The rainfall thresholds should be updated on a regular basis by considering the impacts of regional climate change, cyclone intensities, and resulting rainfall patterns as recommended by the UN Intergovernmental Panel on Climate Change (IPCC) [58]. Finally, activities related to landslide warning integration, dissemination, protective actions such as sheltering, or evacuation, public and stakeholder response, community vulnerability assessment [59], integrating indigenous knowledge, and overall emergency management need special attention for CMA.

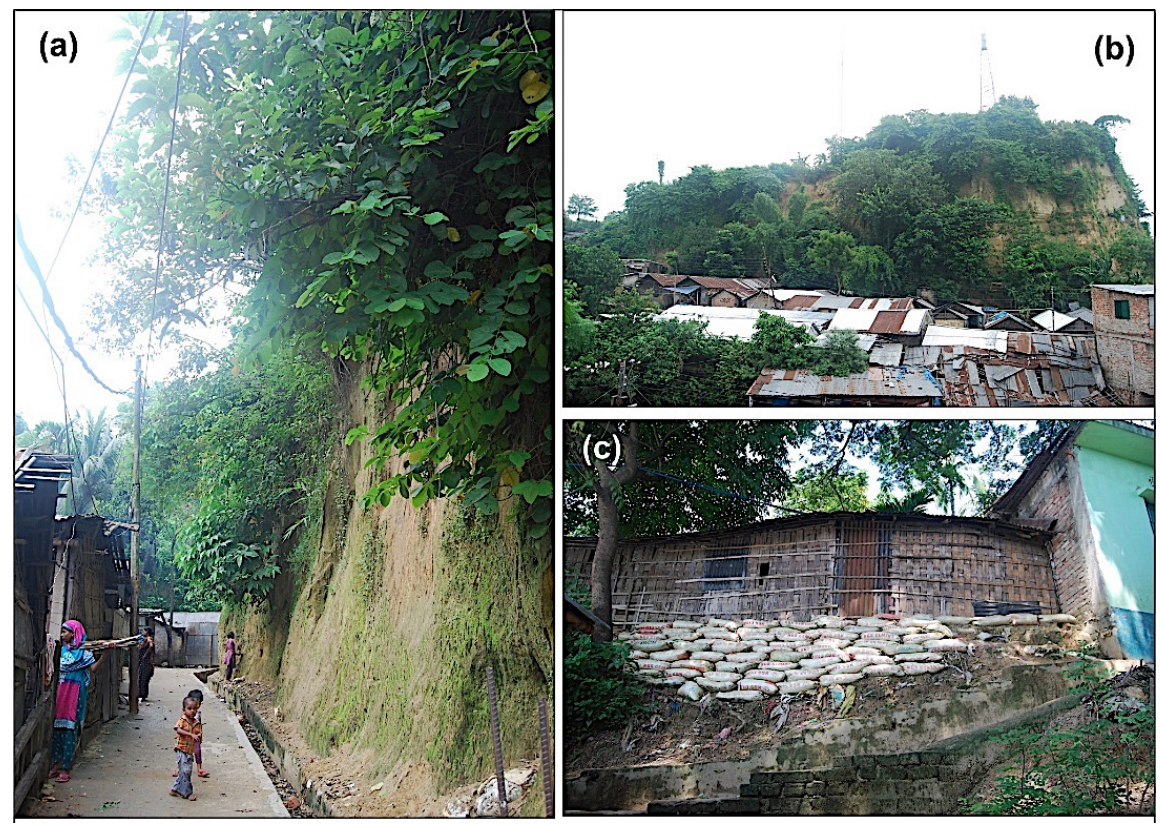

Figure 12. A cluster of houses built on dangerous foothills by cutting hills, where people are living under serious threats of landslides in CMA. Source: Bayes Ahmed, fieldwork, 2015.

\section{Conclusions}

Almost every year, rainfall-triggered landslides affect local communities in the Chittagong Metropolitan Area (CMA), Bangladesh during the monsoon season. Cyclones, flash-flooding, storm surge, and earthquakes are well-known hazards in the CHD region. Conversely, landslides were identified as an emerging disaster since 2012, when 90 local residents were killed in CMA. The extreme population growth and scarcity of flat-lands in CMA have resulted in building housing for the migrants on hazardous slopes by indiscriminately cutting hills. This article proposes a landslide EWS for CMA using cutting-edge Web-GIS technologies to reach the policy makers and local people.

Eleven factor maps were prepared by collecting data from various national organizations and international web-portals. Detailed field surveying was conducted in CMA to prepare a landslide 
inventory map. Four popular models were applied to prepare landslide susceptibility maps. The ANN model generated LSM was selected by applying ROC curves and analyzing spatially agreed areas. Results from the LSMs and rainfall pattern analysis suggest that $70-160 \mathrm{~mm}, 161-250 \mathrm{~mm}$, and $>250 \mathrm{~mm}$ rainfall in five consecutive days can potentially trigger landslides in high, medium, and low susceptible zones. The warning results were validated using a recent landslide event. Access to necessary data, community and stakeholder engagement for warning integration, and the availability of quality datasets were identified as major limitations of this work.

The proposed landslide EWS is original and innovative as it emphasizes on controlling false warnings and is replicable in similar contexts. This work was co-produced with the participation of scientists, local people, and stakeholders to overcome the limitations in landslide warning integration at the local scale. The dynamic landslide web-warning system as developed in this study should be treated as a significant contribution in advancing the field of landslide disaster risk reduction in the Chittagong Hill Districts of Bangladesh.

Author Contributions: B.A. designed the original framework for developing the landslide early warning system for Chittagong, wrote the whole manuscript, conducted the field surveying and performed relevant analyses. M.S.R. took part in field surveying, and prepared the landslide inventory and factor maps. R.I. developed the Web-GIS platform for the dynamic landslide EWS. C.Z. produced the ANN and SVM landslide susceptibility maps. K.U. prepared the land cover map and performed the accuracy assessment. T.M.A.-H. was involved as a key person in the initial part of the work done by BUET-JIDPUS under the ICIMOD Project. All the authors have read, edited, critiqued the manuscript and approved the final version.

Funding: This research was partially funded by the International Centre for Integrated Mountain Development (ICIMOD)/SERVIR-Himalaya Small Grants Programme [Grant ID: SERVIR-H 2014 016]. The APC was partially funded by the University College London (UCL).

Acknowledgments: We want to thank the Chittagong Development Authority (CDA), Chittagong City Corporation (CCC), Department of Environment (DoE), Bangladesh Meteorological Department (BMD), Chittagong University of Engineering and Technology (CUET), University of Chittagong, University of Dhaka, Bangladesh Institute of Planners (BIP), and other stakeholders for sharing their ideas and data with us. We are indebted to the local people for allowing us to enter their communities and helping us to conduct the much-needed fieldworks and arrange community trainings.

Conflicts of Interest: The authors declare no conflict of interest. The affiliated institutions and project funders had no role in the design of the study, in the collection, analyses, or interpretation of data, in the writing of the manuscript, and in the decision to publish the results. On 2 April 2018, the Government of Bangladesh (GoB) made changes in the English spelling of "Chittagong" to "Chattogram", however, we have kept the popular spelling throughout this article.

\section{Appendix A}

Table A1. Details of historical major landslide events in Chittagong District, Bangladesh.

\begin{tabular}{|c|c|c|c|}
\hline Date & Landslide Locations & Rainfall Sequence & Consequences \\
\hline 13/08/1999 & Different locations in Chittagong district & $\begin{array}{l}435 \mathrm{~mm}-12 \text { days } \\
2-13 \text { Aug } 1999\end{array}$ & $\begin{array}{l}17 \text { fatalities, } 350 \\
\text { houses damaged }\end{array}$ \\
\hline $29 / 06 / 2003$ & Patiya, Chittagong & $\begin{array}{l}658 \mathrm{~mm}-10 \text { days } \\
20-29 \text { June } 2003\end{array}$ & 4 fatalities \\
\hline $10 / 07 / 2006$ & Satkania, Chittagong & $\begin{array}{l}231 \mathrm{~mm}-6 \text { days } \\
\text { 4-9 July } 2006\end{array}$ & 2 fatalities \\
\hline $11 / 06 / 2007$ & Different locations in Chittagong city & $\begin{array}{l}610 \mathrm{~mm}-8 \text { days } \\
4-11 \text { June } 2007\end{array}$ & $\begin{array}{l}128 \text { people died } \\
\text { and } 100 \text { injured }\end{array}$ \\
\hline $10 / 09 / 2007$ & Nabi Nagar, Chittagong & $\begin{array}{l}452 \mathrm{~mm}-7 \text { days } \\
4-10 \text { Sept } 2007\end{array}$ & 2 fatalities \\
\hline $18 / 08 / 2008$ & Matijharna, Chittagong City Corporation & $\begin{array}{l}454 \mathrm{~mm}-11 \text { days } \\
\text { 8-18 August } 2008\end{array}$ & $\begin{array}{l}11 \text { fatalities and } \\
25 \text { injured }\end{array}$ \\
\hline $01 / 07 / 2011$ & Batali Hill, Chittagong & $\begin{array}{l}200 \mathrm{~mm}-6 \text { days } \\
25-30 \text { June } 2011\end{array}$ & $\begin{array}{l}19 \text { people died } \\
\text { and many injured }\end{array}$ \\
\hline $26 / 06 / 2012$ & $\begin{array}{l}\text { Lebubagan and Foys lake } \\
\text { surroundings, Chittagong }\end{array}$ & $\begin{array}{l}889 \mathrm{~mm}-8 \text { days } \\
\text { 19-26 June } 2012\end{array}$ & $\begin{array}{l}90 \text { fatalities and } \\
150 \text { injured }\end{array}$ \\
\hline
\end{tabular}


Table A1. Cont.

\begin{tabular}{|c|c|c|c|}
\hline Date & Landslide Locations & Rainfall Sequence & Consequences \\
\hline 28/07/2013 & $\begin{array}{c}\text { Lalkhan Bazar, Chittagong City } \\
\text { Corporation (CCC) }\end{array}$ & $\begin{array}{l}148 \mathrm{~mm}-2 \text { days } \\
26-27 \text { July } 2013\end{array}$ & 2 fatalities \\
\hline $21 / 06 / 2014$ & Pachlaish, Chittagong & $\begin{array}{l}2 \text { days continuous } \\
\text { heavy rainfall }\end{array}$ & $\begin{array}{l}1 \text { dead and } 2 \\
\text { injured }\end{array}$ \\
\hline 23/06/2015 & DT Road Rail Gate, Chittagong & $\begin{array}{l}\text { Wall collapse due to } 2 \text { days } \\
\text { heavy rainfall }\end{array}$ & 2 dead \\
\hline 19/07/2015 & Motijharna and Tankir Pahar, Chittagong & $\begin{array}{l}205 \mathrm{~mm}-5 \text { days } \\
15-19 \text { July } 2015\end{array}$ & 6 dead \\
\hline $13 / 06 / 2017$ & All five hill districts & $\begin{array}{l}\text { Several days of } \\
\text { continuous rainfall }\end{array}$ & $\begin{array}{l}159 \text { dead and } 88 \\
\text { injured }\end{array}$ \\
\hline 21/07/2017 & Sitakunda, Chittagong & $\begin{array}{l}\text { Several days of } \\
\text { continuous rainfall }\end{array}$ & 5 fatalities \\
\hline $14 / 10 / 2018$ & $\begin{array}{c}\text { Akbar Shah area's Firoz Shah Colony, and } \\
\text { Panchlaish's Rahman Nagar area }\end{array}$ & $\begin{array}{l}464 \mathrm{~mm}-5 \text { days } \\
09-13 \text { October } 2018\end{array}$ & $\begin{array}{l}4 \text { people were } \\
\text { killed }\end{array}$ \\
\hline
\end{tabular}

Source: [9]; and national daily newspapers.

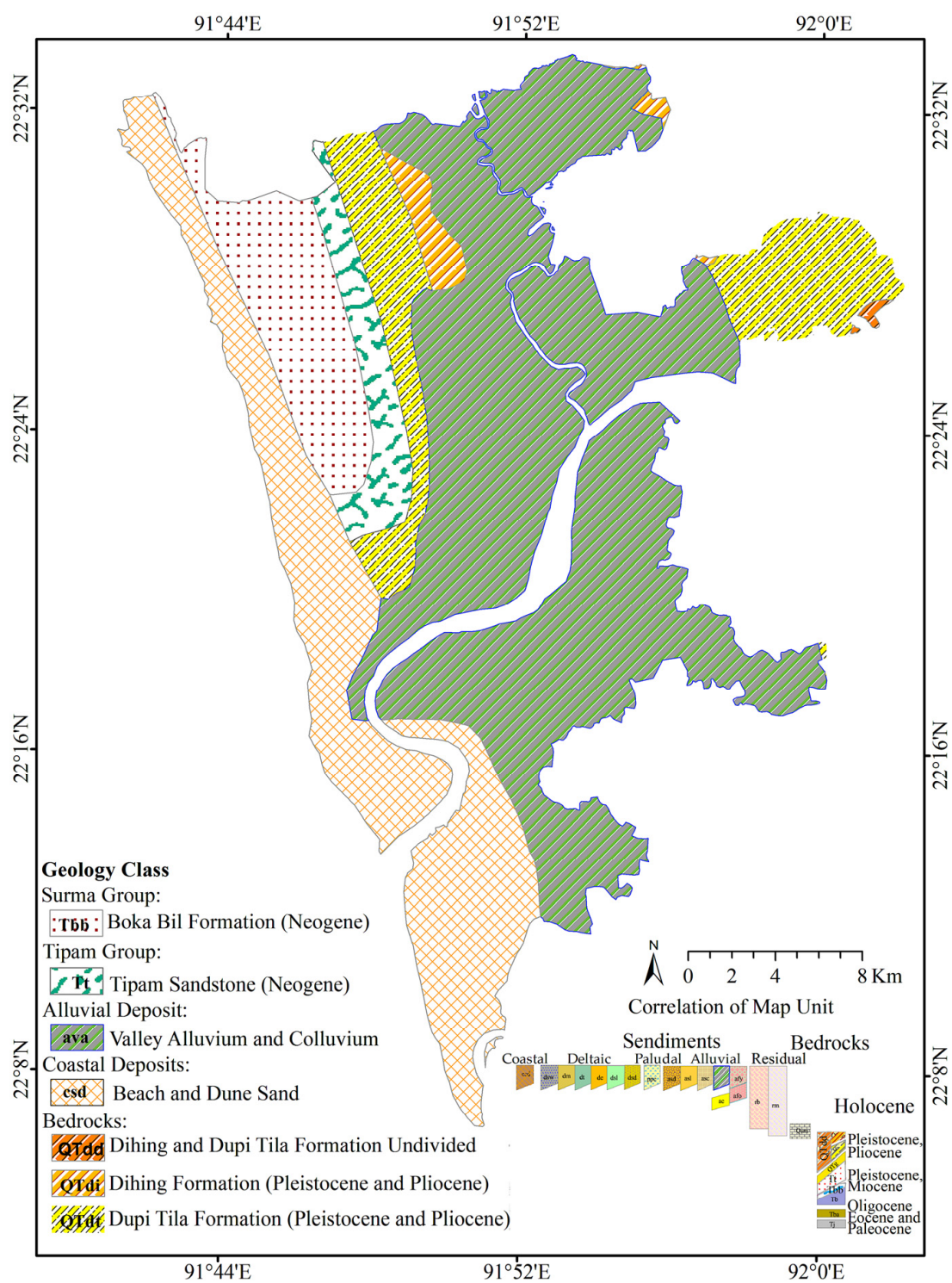

Figure A1. Geological map of Chittagong Metropolitan Area, Bangladesh. Source: Geological Survey of Bangladesh (GSB) [60]. 


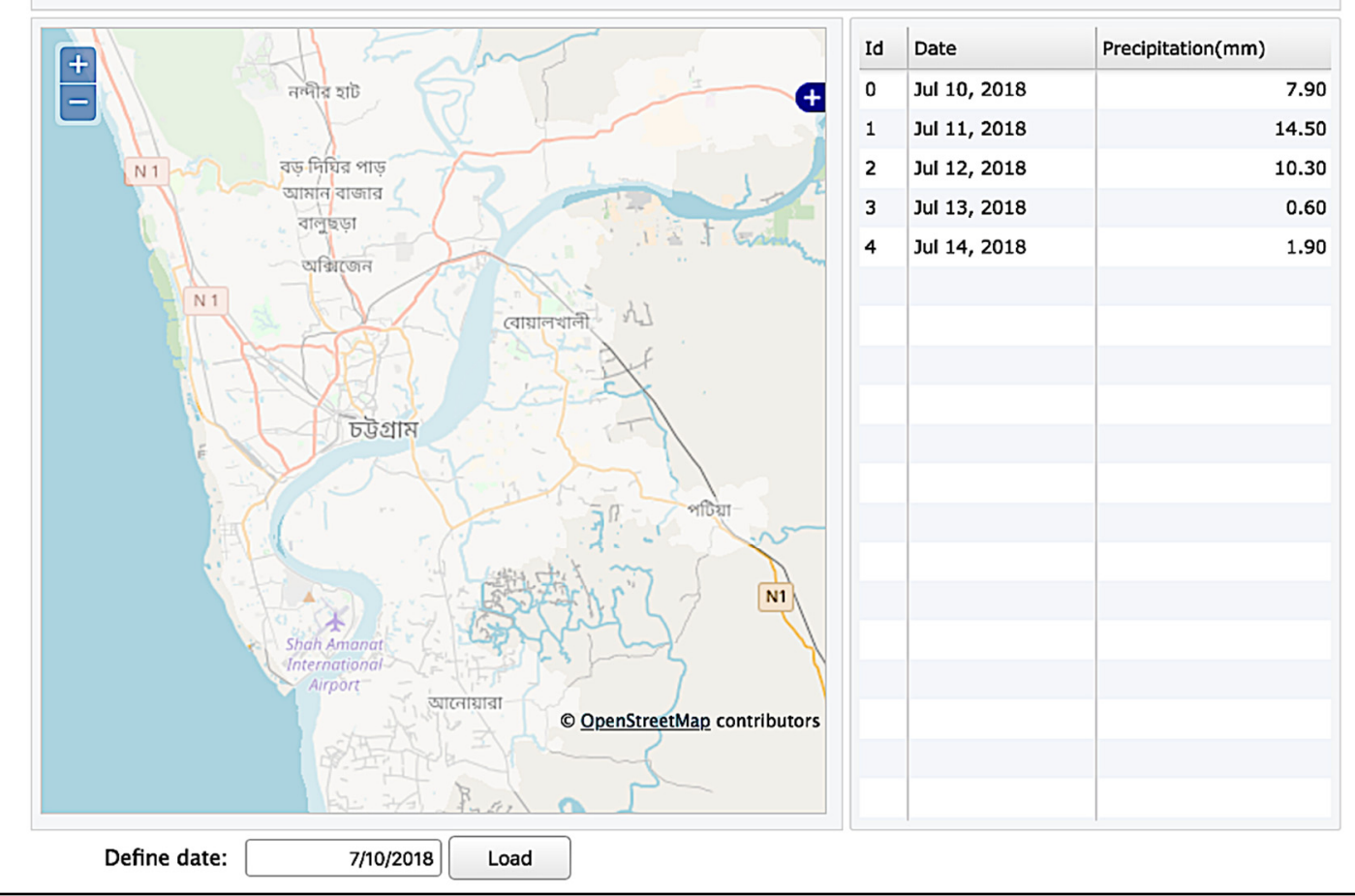

Chittagong Metropolitan Area, Bangladesh

(b)

$\square$ Receive alerts $\square$ Last 30 days $\square$ Forecast Insert manually

$120.95 \mathrm{~mm}$ in $\mathbf{5}$ day(s)

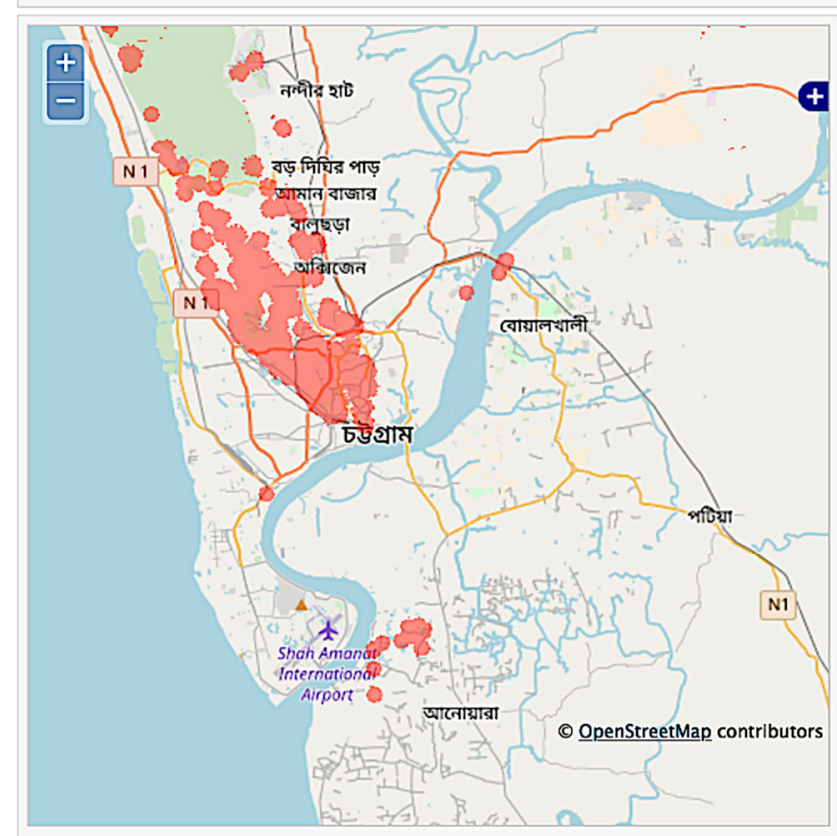

\begin{tabular}{|l|l|r|}
\hline Id & Date & Precipitation(mm) \\
\hline 0 & Jul 10, 2018 & 21.20 \\
\hline 1 & Jul 9, 2018 & 4.30 \\
2 & Jul 8, 2018 & 9.93 \\
3 & Jul 7, 2018 & 5.30 \\
\hline 4 & Jul 6, 2018 & 8.58 \\
5 & Jul 5, 2018 & 1.20 \\
\hline 6 & Jul 4, 2018 & 84.83 \\
\hline 7 & Jul 3, 2018 & 75.62 \\
8 & Jul 2, 2018 & 22.37 \\
9 & Jul 1, 2018 & 11.34 \\
\hline 10 & Jun 30, 2018 & 9.75 \\
11 & Jun 29, 2018 & 1.87 \\
\hline 12 & Jun 28, 2018 & 1.56 \\
\hline 13 & Jun 27, 2018 & 3.91 \\
\hline 14 & Jun 26, 2018 & 7.65 \\
15 & Jun 25, 2018 & 25.45 \\
\hline 16 & Jun 24, 2018 & 52.85 \\
17 & Jun 23, 2018 & 48.67 \\
\hline 18 & Jun 22, 2018 & 22.06 \\
\hline & & \\
\hline
\end{tabular}

Define date:

7/10/2018 Load

Figure A2. Cont. 


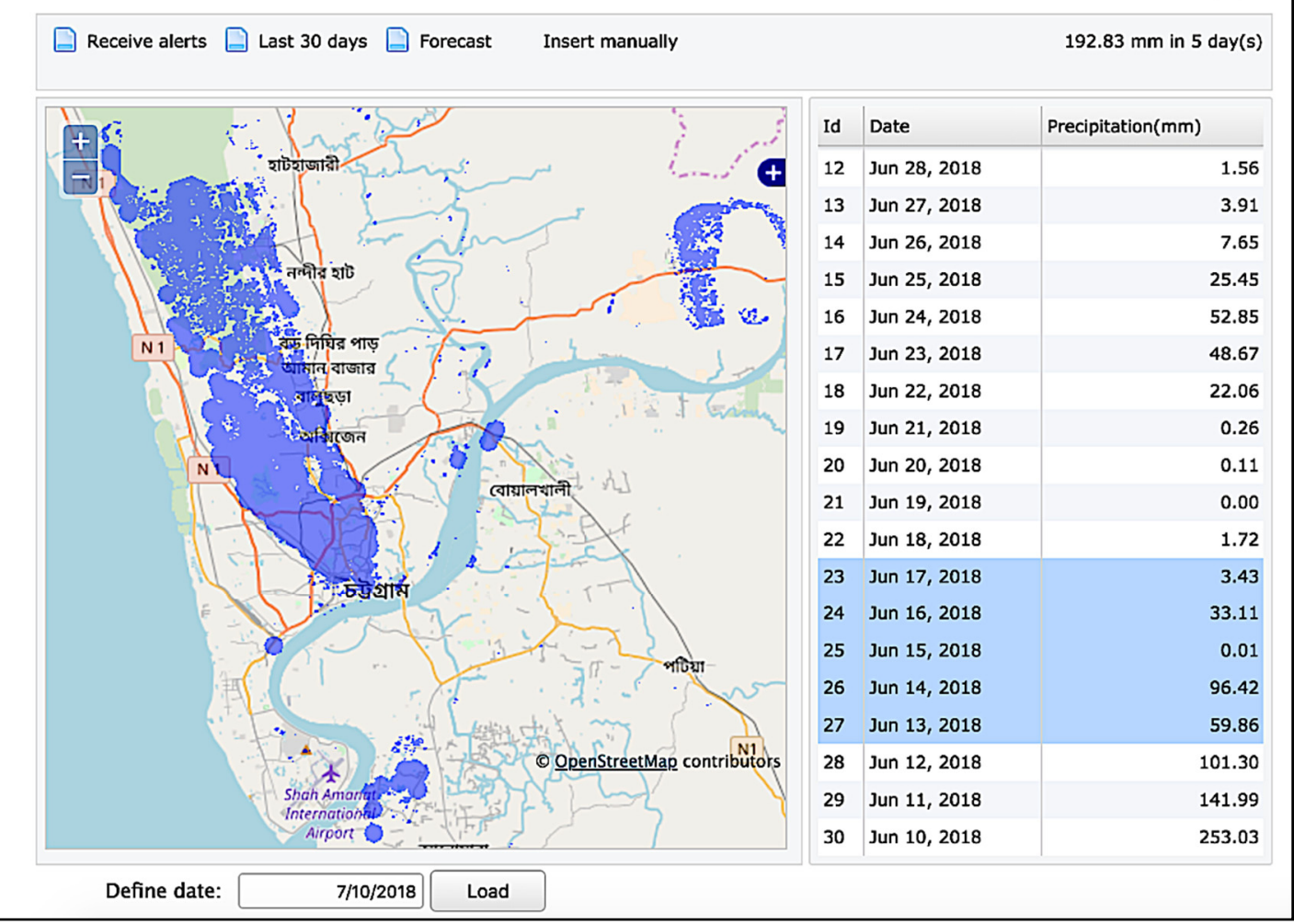

Chittagong Metropolitan Area, Bangladesh

Receive alerts $D$ Last 30 days $D$ Forecast Insert manually

$652.6 \mathrm{~mm}$ in 5 day(s)

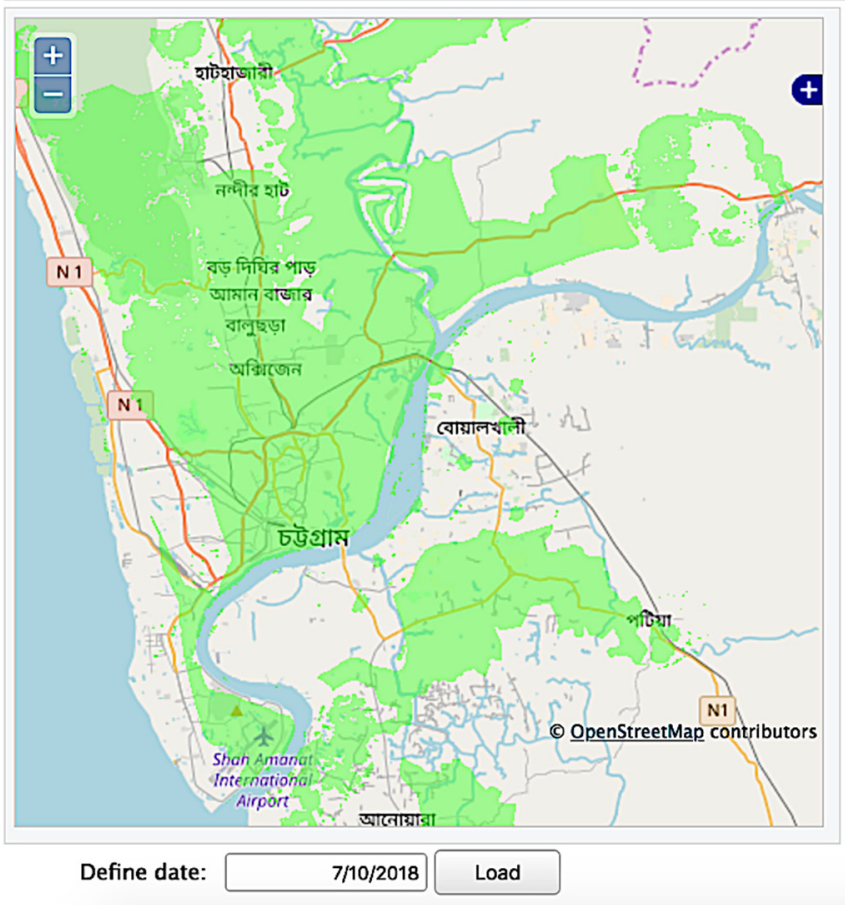

\begin{tabular}{|l|l|r|}
\hline Id & Date & Precipitation(mm) \\
\hline 12 & Jun 28, 2018 & 1.56 \\
\hline 13 & Jun 27, 2018 & 3.91 \\
14 & Jun 26, 2018 & 7.65 \\
15 & Jun 25, 2018 & 25.45 \\
\hline 16 & Jun 24, 2018 & 52.85 \\
\hline 17 & Jun 23, 2018 & 48.67 \\
\hline 18 & Jun 22, 2018 & 22.06 \\
19 & Jun 21, 2018 & 0.26 \\
\hline 20 & Jun 20, 2018 & 0.11 \\
\hline 21 & Jun 19, 2018 & 0.00 \\
\hline 22 & Jun 18, 2018 & 1.72 \\
\hline 23 & Jun 17, 2018 & 3.43 \\
\hline 24 & Jun 16, 2018 & 33.11 \\
\hline 25 & Jun 15, 2018 & 0.01 \\
\hline 26 & Jun 14, 2018 & 96.42 \\
\hline 27 & Jun 13, 2018 & 59.86 \\
\hline 28 & Jun 12, 2018 & 101.30 \\
29 & Jun 11, 2018 & 141.99 \\
\hline 30 & Jun 10, 2018 & 253.03 \\
\hline & & \\
\hline
\end{tabular}

Figure A2. Screen-shots from the EWS developed for CMA showing: (a) zones not reaching the appropriate rainfall threshold in 5-consecutive days $(<71 \mathrm{~mm})$; and the delineation of (b) high; (c) medium; and (d) low landslide warning zones. Source: http:/ /www.landslidebd.com/ctg-warningsystem/; accessed on 10 July 2018. 


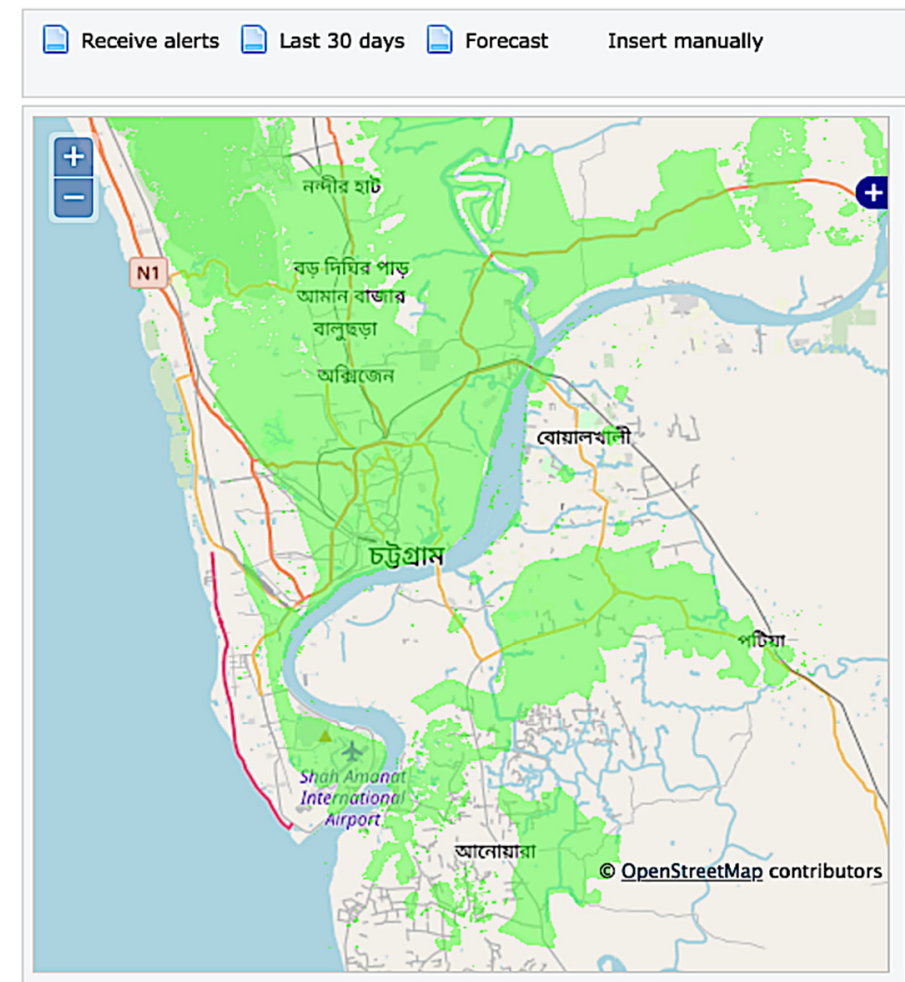

\begin{tabular}{|l|l|r|}
\hline \multicolumn{2}{|c|}{} & $463.64 \mathrm{~mm}$ in 5 day(s) \\
\hline Id & Date & Precipitation(mm) \\
\hline 0 & Oct 14, 2018 & 19.60 \\
\hline 1 & Oct 13, 2018 & 61.70 \\
\hline 2 & Oct 12, 2018 & 41.00 \\
\hline 3 & Oct 11, 2018 & 297.27 \\
\hline 4 & Oct 10, 2018 & 28.95 \\
\hline 5 & Oct 9, 2018 & 34.72 \\
6 & Oct 8, 2018 & 2.43 \\
7 & Oct 7, 2018 & 0.00 \\
\hline 8 & Oct 6, 2018 & 1.58 \\
\hline 9 & Oct 5, 2018 & 1.70 \\
\hline 10 & Oct 4, 2018 & 3.11 \\
\hline 11 & Oct 3, 2018 & 1.09 \\
\hline 12 & Oct 2, 2018 & 0.48 \\
\hline 13 & Oct 1, 2018 & 1.23 \\
\hline 14 & Sep 30, 2018 & 0.98 \\
15 & Sep 29, 2018 & 0.69 \\
\hline 16 & Sep 28, 2018 & 0.62 \\
\hline 17 & Sep 27, 2018 & 0.09 \\
\hline 18 & Sep 26, 2018 & 18.18 \\
\hline
\end{tabular}

Landslidedb.com system@landslidedb.com via gator3175.hostgator.com Oct $9,2018,8: 00$ AM ( 5 days ago) to me $\checkmark$

...

This email is generated by the Landslidedb system.

The areas affected by a precipation of Cumulative $>250 \mathrm{~mm}$ in 5 days are shown in next link

\section{View Map}

The alert is generated based on forecasted precipitation data of World Weather Online

Landslidedb.com system@landslidedb.com via gator3175.hostgator.com Mon, Oct 8, 11:00 PM (6 days ago)

to me -

...

This email is generated by the Landslidedb system.

The areas affected by a precipation of Cumulative $>250 \mathrm{~mm}$ in 5 days are shown in next link

\section{View Map}

The alert is generated based on forecasted precipitation data of World Weather Online

Figure A3. Screen-shots from the EWS developed for CMA showing: (a) alert validation for the 14 October 2018 event; and (b,c) advanced email notifications (as seen by a subscriber). Source: http: / / www.landslidebd.com/ctg-warning-system/; accessed on 14 October 2018. 
Table A2. Calculations showing spatially agreed areas and proportions of observed landslides.

\begin{tabular}{|c|c|c|c|c|c|c|c|}
\hline \multirow[b]{2}{*}{ SVM } & \multirow[b]{2}{*}{ ANN } & \multicolumn{3}{|c|}{ Study Area } & \multicolumn{3}{|c|}{ Observed Landslide Area } \\
\hline & & $\begin{array}{l}\text { Area } \\
\text { Pixel }\end{array}$ & $\begin{array}{c}\text { Area } \\
\left(\mathbf{k m}^{2}\right)\end{array}$ & $\%$ & $\begin{array}{l}\text { Area } \\
\text { Pixel }\end{array}$ & $\begin{array}{c}\text { Area } \\
\left(\mathrm{km}^{2}\right)\end{array}$ & $\%$ \\
\hline \multirow{4}{*}{ None } & None & 585,642 & 527.08 & 77.54 & 7 & 0.01 & 3.98 \\
\hline & Low & 130,292 & 117.26 & 17.25 & 12 & 0.01 & 6.82 \\
\hline & Medium & 17,340 & 15.61 & 2.30 & 19 & 0.02 & 10.80 \\
\hline & High & 4006 & 3.61 & 0.53 & 6 & 0.01 & 3.41 \\
\hline \multirow{4}{*}{ Low } & None & 776 & 0.70 & 0.10 & 1 & 0.00 & 0.57 \\
\hline & Low & 1084 & 0.98 & 0.14 & 0 & 0.00 & 0.00 \\
\hline & Medium & 2169 & 1.95 & 0.29 & 2 & 0.00 & 1.14 \\
\hline & High & 1599 & 1.44 & 0.21 & 2 & 0.00 & 1.14 \\
\hline \multirow{4}{*}{ Medium } & None & 204 & 0.18 & 0.03 & 0 & 0.00 & 0.00 \\
\hline & Low & 521 & 0.47 & 0.07 & 0 & 0.00 & 0.00 \\
\hline & Medium & 1351 & 1.22 & 0.18 & 1 & 0.00 & 0.57 \\
\hline & High & 1507 & 1.36 & 0.20 & 5 & 0.00 & 2.84 \\
\hline \multirow{4}{*}{ High } & None & 122 & 0.11 & 0.02 & 2 & 0.00 & 1.14 \\
\hline & Low & 240 & 0.22 & 0.03 & 1 & 0.00 & 0.57 \\
\hline & Medium & 1851 & 1.67 & 0.25 & 11 & 0.01 & 6.25 \\
\hline & High & 6615 & 5.95 & 0.88 & 107 & 0.10 & 60.80 \\
\hline \multirow{2}{*}{$\begin{array}{c}\text { Total Area } \\
\text { Total Agreed } \\
\text { Area }\end{array}$} & & 755,319 & 679.79 & 100.00 & 176 & 0.16 & 100.00 \\
\hline & & 594,692 & 535.20 & 78.73 & 115 & 0.10 & 65.34 \\
\hline & & \multicolumn{3}{|c|}{ Study Area } & \multicolumn{3}{|c|}{ Observed Landslide Area } \\
\hline SVM & PCA_MR & $\begin{array}{l}\text { Area } \\
\text { Pixel }\end{array}$ & $\begin{array}{c}\text { Area } \\
\left(\mathrm{km}^{2}\right)\end{array}$ & $\%$ & $\begin{array}{l}\text { Area } \\
\text { Pixel }\end{array}$ & $\begin{array}{c}\text { Area } \\
\left(\mathrm{km}^{2}\right)\end{array}$ & $\%$ \\
\hline \multirow{4}{*}{ None } & None & 271,475 & 244.33 & 35.94 & 0 & 0.00 & 0.00 \\
\hline & Low & 248,840 & 223.96 & 32.95 & 6 & 0.01 & 3.41 \\
\hline & Medium & 137,794 & 124.01 & 18.24 & 11 & 0.01 & 6.25 \\
\hline & High & 79,171 & 71.25 & 10.48 & 27 & 0.02 & 15.34 \\
\hline \multirow{4}{*}{ Low } & None & 1 & 0.00 & 0.00 & 0 & 0.00 & 0.00 \\
\hline & Low & 609 & 0.55 & 0.08 & 0 & 0.00 & 0.00 \\
\hline & Medium & 1313 & 1.18 & 0.17 & 0 & 0.00 & 0.00 \\
\hline & High & 3705 & 3.33 & 0.49 & 5 & 0.00 & 2.84 \\
\hline \multirow{4}{*}{ Medium } & None & 3 & 0.00 & 0.00 & 0 & 0.00 & 0.00 \\
\hline & Low & 228 & 0.21 & 0.03 & 0 & 0.00 & 0.00 \\
\hline & Medium & 758 & 0.68 & 0.10 & 0 & 0.00 & 0.00 \\
\hline & High & 2594 & 2.33 & 0.34 & 6 & 0.01 & 3.41 \\
\hline \multirow{4}{*}{ High } & None & 0 & 0.00 & 0.00 & 0 & 0.00 & 0.00 \\
\hline & Low & 260 & 0.23 & 0.03 & 3 & 0.00 & 1.70 \\
\hline & Medium & 1138 & 1.02 & 0.15 & 21 & 0.02 & 11.93 \\
\hline & High & 7430 & 6.69 & 0.98 & 97 & 0.09 & 55.11 \\
\hline \multirow{2}{*}{$\begin{array}{c}\text { Total Area } \\
\text { Total Agreed } \\
\text { Area }\end{array}$} & & 755,319 & 679.79 & 100.00 & 176 & 0.16 & 100.00 \\
\hline & & 280,272 & 252.24 & 37.11 & 97 & 0.09 & 55.11 \\
\hline \multirow{3}{*}{ SVM } & & \multicolumn{3}{|c|}{ Study Area } & \multicolumn{3}{|c|}{ Observed Landslide Area } \\
\hline & MR & $\begin{array}{l}\text { Area } \\
\text { Pixel }\end{array}$ & $\begin{array}{c}\text { Area } \\
\left(\mathrm{km}^{2}\right)\end{array}$ & $\%$ & $\begin{array}{l}\text { Area } \\
\text { Pixel }\end{array}$ & $\begin{array}{c}\text { Area } \\
\left(\mathrm{km}^{2}\right)\end{array}$ & $\%$ \\
\hline & None & 371,927 & 334.73 & 49.24 & 1 & 0.00 & 0.57 \\
\hline \multirow{3}{*}{ None } & Low & 328,215 & 295.39 & 43.45 & 10 & 0.01 & 5.68 \\
\hline & Medium & 19,594 & 17.63 & 2.59 & 8 & 0.01 & 4.55 \\
\hline & High & 17,544 & 15.79 & 2.32 & 25 & 0.02 & 14.20 \\
\hline & None & 385 & 0.35 & 0.05 & 0 & 0.00 & 0.00 \\
\hline & Low & 1202 & 1.08 & 0.16 & 3 & 0.00 & 1.70 \\
\hline Low & Medium & 1297 & 1.17 & 0.17 & 0 & 0.00 & 0.00 \\
\hline & High & 2744 & 2.47 & 0.36 & 2 & 0.00 & 1.14 \\
\hline
\end{tabular}


Table A2. Cont.

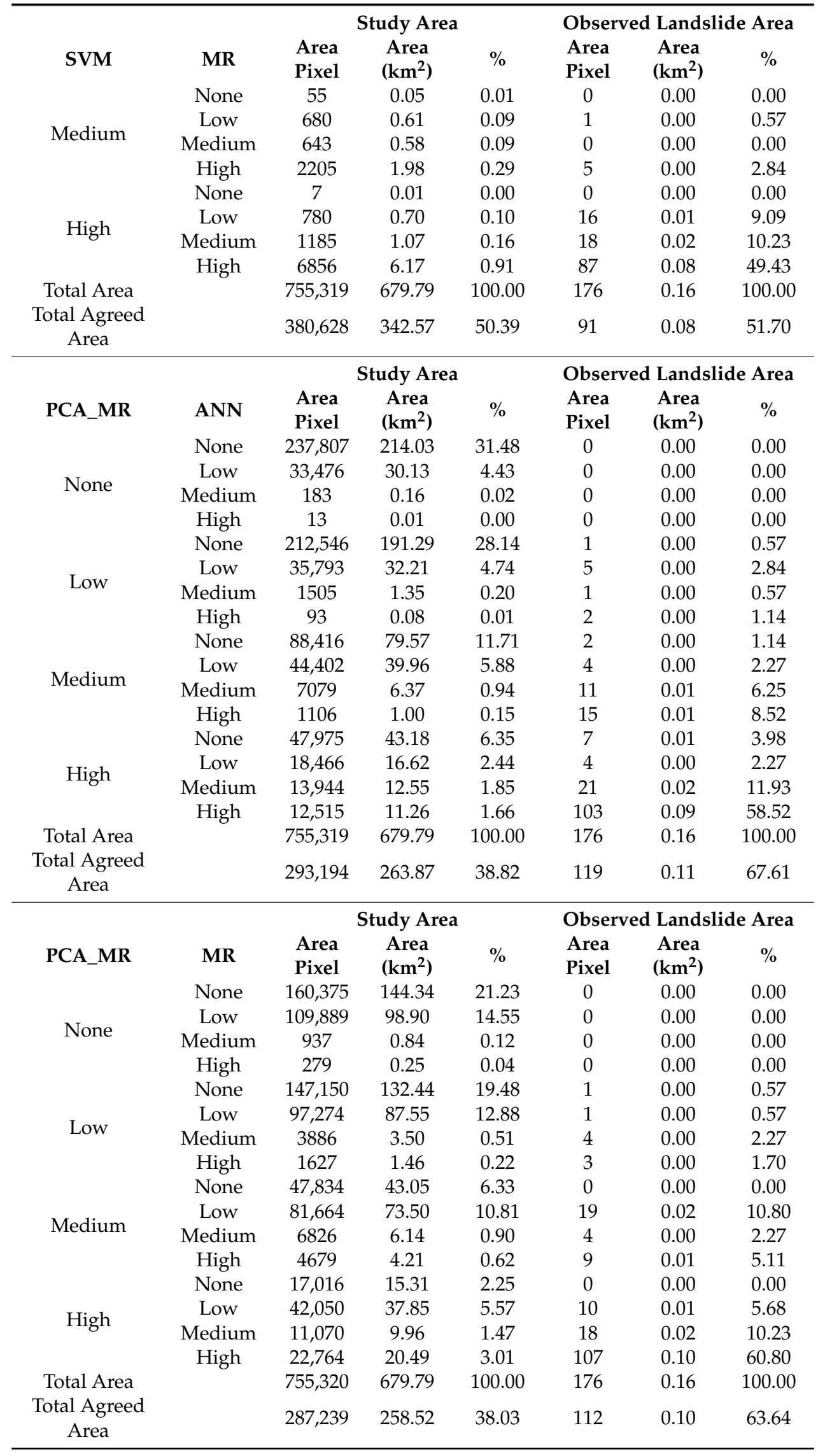


Table A2. Cont.

\begin{tabular}{|c|c|c|c|c|c|c|c|}
\hline \multirow[b]{2}{*}{ MR } & \multirow[b]{2}{*}{ ANN } & \multicolumn{3}{|c|}{ Study Area } & \multicolumn{3}{|c|}{ Observed Landslide Area } \\
\hline & & $\begin{array}{l}\text { Area } \\
\text { Pixel }\end{array}$ & $\begin{array}{c}\text { Area } \\
\left(\mathrm{km}^{2}\right)\end{array}$ & $\%$ & $\begin{array}{l}\text { Area } \\
\text { Pixel }\end{array}$ & $\begin{array}{c}\text { Area } \\
\left(\mathrm{km}^{2}\right)\end{array}$ & $\%$ \\
\hline \multirow{4}{*}{ None } & None & 305,784 & 275.21 & 40.48 & 1 & 0.00 & 0.57 \\
\hline & Low & 65,757 & 59.18 & 8.71 & 0 & 0.00 & 0.00 \\
\hline & Medium & 827 & 0.74 & 0.11 & 0 & 0.00 & 0.00 \\
\hline & High & 6 & 0.01 & 0.00 & 0 & 0.00 & 0.00 \\
\hline \multirow{4}{*}{ Low } & None & 269,705 & 242.73 & 35.71 & 3 & 0.00 & 1.70 \\
\hline & Low & 54,235 & 48.81 & 7.18 & 4 & 0.00 & 2.27 \\
\hline & Medium & 6651 & 5.99 & 0.88 & 16 & 0.01 & 9.09 \\
\hline & High & 286 & 0.26 & 0.04 & 7 & 0.01 & 3.98 \\
\hline \multirow{4}{*}{ Medium } & None & 8166 & 7.35 & 1.08 & 3 & 0.00 & 1.70 \\
\hline & Low & 7218 & 6.50 & 0.96 & 3 & 0.00 & 1.70 \\
\hline & Medium & 5912 & 5.32 & 0.78 & 2 & 0.00 & 1.14 \\
\hline & High & 1423 & 1.28 & 0.19 & 18 & 0.02 & 10.23 \\
\hline \multirow{4}{*}{ High } & None & 3089 & 2.78 & 0.41 & 3 & 0.00 & 1.70 \\
\hline & Low & 4927 & 4.43 & 0.65 & 6 & 0.01 & 3.41 \\
\hline & Medium & 9321 & 8.39 & 1.23 & 15 & 0.01 & 8.52 \\
\hline & High & 12,012 & 10.81 & 1.59 & 95 & 0.09 & 53.98 \\
\hline Total Area & & 755,319 & 679.79 & 100.00 & 176 & 0.16 & 100.00 \\
\hline $\begin{array}{c}\text { Total Agreed } \\
\text { Area }\end{array}$ & & 377,943 & 340.15 & 50.04 & 102 & 0.09 & 57.95 \\
\hline
\end{tabular}
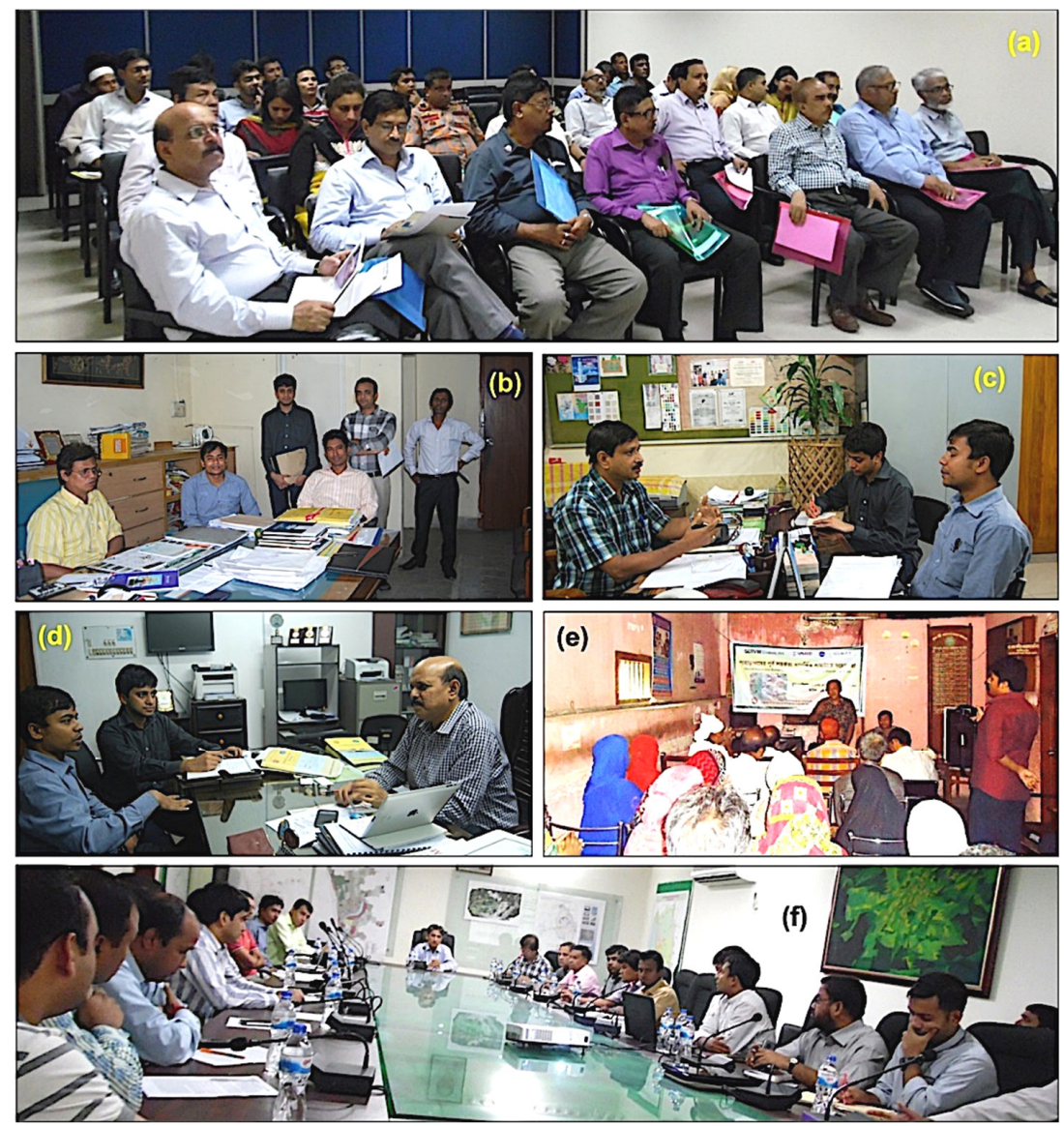

Figure A4. Photographs of (a) national seminar on landslide disaster management in Bangladesh University of Engineering and Technology (BUET), Dhaka; expert opinion surveying with the (b) chief town planner, CDA; (c) chief architect and town planner, CCC; (d) director, DoE, Chittagong; (e) knowledge sharing meeting with the Motijharna community; and (f) with the CDA Chairman and CDA officials in Chittagong, Bangladesh. Source: Bayes Ahmed, fieldwork, 2014-15. 


\section{References}

1. Disasters in Asia and the Pacific: 2015 year in review. In United Nations (UN) Report. Economic and Social Commission for Asia and the Pacific (ESCAP); UN ESCAP: Bangkok, Thailand, 2015.

2. Van Westen, C.J.; Quan Luna, B.; Vargas Franco, R.; Malet, J.P.; Jaboyedoff, M.; Horton, P.; Kappes, M. Development of training materials on the use of geo-information for multi-hazard risk assessment in a mountainous environment. In Proceedings of the Mountain Risks International Conference, Firenze, Italy, 24 November 2010; pp. 24-26.

3. Kirschbaum, D.B.; Adler, R.; Hong, Y.; Hill, S.; Lerner-Lam, A. A global landslide catalog for hazard applications: Method, results, and limitations. Nat. Hazards 2010, 52, 561-575. [CrossRef]

4. Petley, D.N.; Dunning, S.A.; Rosser, N.J.; Hungr, O. The Analysis of Global Landslide Risk Through the Creation of a Database of Worldwide Landslide Fatalities. Landslide Risk Management; Taylor and Francis Group: London, UK, 2005; pp. 367-374.

5. WU, C. Comparison and Evolution of Extreme Rainfall-Induced Landslides in Taiwan. ISPRS Int. J. Geo-Inf. 2017, 6, 367. [CrossRef]

6. Shrestha, S.; Kang, T.-S.; Suwal, M.K. An Ensemble Model for Co-Seismic Landslide Susceptibility Using GIS and Random Forest Method. ISPRS Int. J. Geo-Inf. 2017, 6, 365. [CrossRef]

7. Rabby, Y.W.; Li, Y. An integrated approach to map landslides in Chittagong Hilly Areas, Bangladesh, using Google Earth and field mapping. Landslides 2018. [CrossRef]

8. Japan Hit by Worst Weather Disaster in Decades: Why Did so Many Die? Available online: https: / / www.reuters.com/article/us-weather-japan-explainer/japan-hit-by-worst-weather-disaster-indecades-why-did-so-many-die-idUSKBN1K10ET (accessed on 18 December 2018).

9. Ahmed, B. Community Vulnerability to Landslides in Bangladesh. Ph.D Thesis, University College London, London, UK, 2017.

10. Ahmed, B. Landslide susceptibility mapping using multi-criteria evaluation techniques in Chittagong Metropolitan Area, Bangladesh. Landslides 2015, 12, 1077-1095. [CrossRef]

11. Ahmed, B. Landslide susceptibility modelling applying user-defined weighting and data-driven statistical techniques in Cox's Bazar Municipality, Bangladesh. Nat. Hazards 2015, 79, 1707-1737. [CrossRef]

12. Rahman, M.S.; Ahmed, B.; Di, L. Landslide initiation and runout susceptibility modeling in the context of hill cutting and rapid urbanization: A combined approach of weights of evidence and spatial multi-criteria. J. Mt. Sci. 2017, 14, 1919-1937. [CrossRef]

13. Ahmed, B.; Dewan, A. Application of bivariate and multivariate statistical techniques in landslide susceptibility modeling in Chittagong City Corporation, Bangladesh. Remote Sens. 2017, 9, 304. [CrossRef]

14. Kelman, I.; Ahmed, B.; Esraz-Ul-Zannat, M.; Saroar, M.M.; Fordham, M.; Shamsudduha, M. Warning systems as social processes for Bangladesh cyclones. Dis. Prev. Manag. Int. J. 2018, 27, 370-379. [CrossRef]

15. Kelman, I.; Glantz, M.H. Early warning systems defined. In Reducing Disaster: Early Warning Systems for Climate Change; Springer: Heidelberg, Germany, 2014; pp. 89-108.

16. Kelman, I. Warning for the 26 December 2004 tsunamis. Dis. Prev. Manag. Int. J. 2006, 15, 178-189. [CrossRef]

17. Intrieri, E.; Gigli, G.; Mugnai, F.; Fanti, R.; Casagli, N. Design and implementation of a landslide early warning system. Eng. Geol. 2012, 147, 124-136. [CrossRef]

18. Michoud, C.; Bazin, S.; Blikra, L.H.; Derron, M.-H.; Jaboyedoff, M. Experiences from site-specific landslide early warning systems. Nat. Hazards Earth Syst. Sci. 2013, 13, 2659-2673. [CrossRef]

19. Segoni, S.; Rosi, A.; Rossi, G.; Catani, F.; Casagli, N. Analysing the relationship between rainfalls and landslides to define a mosaic of triggering thresholds for regional-scale warning systems. Nat. Hazards Earth Syst. Sci. 2014, 14, 2637-2648. [CrossRef]

20. Calvello, M.; d'Orsi, R.N.; Piciullo, L.; Paes, N.; Magalhaes, M.; Lacerda, W.A. The Rio de Janeiro early warning system for rainfall-induced landslides: Analysis of performance for the years 2010-2013. Int. J. Disaster Risk Reduct. 2015, 12, 3-15. [CrossRef]

21. Caine, N. The rainfall intensity-duration control of shallow landslides and debris flows. Geografiska Annal. 1980, 62, 23-27.

22. Kirschbaum, D.; Stanley, T. Satellite-Based Assessment of Rainfall-Triggered Landslide Hazard for Situational Awareness. Earth's Future 2018, 6, 505-523. [CrossRef] 
23. Segoni, S.; Battistini, A.; Rossi, G.; Rosi, A.; Lagomarsino, D.; Catani, F.; Moretti, S.; Casagli, N. An operational landslide early warning system at regional scale based on space-time-variable rainfall thresholds. Nat. Hazards Earth Syst. Sci. 2015, 15, 853-861. [CrossRef]

24. Glade, T.; Crozier, M.; Smith, P. Applying probability determination to refine landslide-triggering rainfall thresholds using an empirical “Antecedent Daily Rainfall Model”. Pure Appl. Geophys. 2000, 157, 1059-1079. [CrossRef]

25. Wieczorek, G.F.; Glade, T. Climatic Factors Influencing Occurrence of Debris Flows. In Debris-Flow Hazards and Related Phenomena; Springer: Berlin, Heidelberg, 2005; pp. 325-362.

26. Gabet, E.J.; Burbank, D.W.; Putkonen, J.K.; Pratt-Sitaula, B.A.; Ojha, T. Rainfall thresholds for landsliding in the Himalayas of Nepal. Geomorphology 2004, 63, 131-143. [CrossRef]

27. Peruccacci, S.; Brunetti, M.T.; Gariano, S.L.; Melillo, M.; Rossi, M.; Guzzetti, F. Rainfall thresholds for possible landslide occurrence in Italy. Geomorphology 2017, 290, 39-57. [CrossRef]

28. Mirus, B.B.; Becker, R.E.; Baum, R.L.; Smith, J.B. Integrating real-time subsurface hydrologic monitoring with empirical rainfall thresholds to improve landslide early warning. Landslides 2018, 15, 1909-1919. [CrossRef]

29. Segoni, S.; Rosi, A.; Lagomarsino, D.; Fanti, R.; Casagli, N. Brief communication: Using averaged soil moisture estimates to improve the performances of a regional-scale landslide early warning system. Nat. Hazards Earth Syst. Sci. 2018, 18, 807-812. [CrossRef]

30. Liao, Z.; Hong, Y.; Wang, J.; Fukuoka, H.; Sassa, K.; Karnawati, D.; Fathani, F. Prototyping an experimental early warning system for rainfall-induced landslides in Indonesia using satellite remote sensing and geospatial datasets. Landslides 2010, 7, 317-324. [CrossRef]

31. Lagomarsino, D.; Segoni, S.; Fanti, R.; Catani, F. Updating and tuning a regional-scale landslide early warning system. Landslides 2013, 10, 91-97. [CrossRef]

32. CDMP-II Rainfall Triggered Landslide Hazard Zonation in Cox's Bazar E Teknaf Municipalities as well as Introducing Community-based Early Warning System for Landslide Hazard Management; Ministry of Food and Disaster Management (MoFDM): Dhaka, Bangladesh, 2012.

33. CDMP II Landslide Inventory and Landuse Mapping, DEM Preparation, Precipitation Threshold Value and Establishment of Early Warning Device; Comprehensive Disaster Management Programme-II (CDMP-II); Ministry of Food and Disaster Management (MoFDM) Disaster Management and Relief Division (DMRD) Government of the People's Republic of Bangladesh: Dhaka, Bangladesh, 2012.

34. BBS District Statistics 2011-Chittagong. Bangladesh Bureau of Statistics; Statistics and Informatics Division (SID), Ministry of Planning, Parishankhan Bhaban, E-27/A, Agargaon, Dhaka-1207; Government of the People's Republic of Bangladesh: Dhaka, Bangladesh, 2013.

35. Brammer, H. Physical Geography of Bangladesh; The University Press Ltd.: Dhaka, Bangladesh, 2012.

36. Ahmed, B.; Rahman, M.S.; Rahman, S.; Huq, F.F.; Ara, S. Landslide Inventory Report of Chittagong Metropolitan Area, Bangladesh; BUET-Japan Institute of Disaster Prevention and Urban Safety: Dhaka, Bangladesh, 2014.

37. Rahman, M.S.; Ahmed, B.; Huq, F.F.; Rahman, S.; Al-Hussaini, T. Landslide inventory in an urban setting in the context of Chittagong Metropolitan Area, Bangladesh. In Proceedings of the 3rd International Conference on Advances in Civil Engineering, Chittagong, Bangladesh, 21-23 December 2016.

38. Daily Observational Data Map: GIS Maps. National Oceanic and Atmospheric Administration (NOAA). Available online: https:/ / www.ncdc.noaa.gov/maps/ (accessed on 5 August 2018).

39. Ahmed, B.; Ahmed, R. Modeling urban land cover growth dynamics using multi-temporal satellite images: A case study of Dhaka, Bangladesh. ISPRS Int. J. Geo-Inf. 2012, 1, 3-31. [CrossRef]

40. Ahmed, B.; Ahmed, R.; Zhu, X. Evaluation of model validation techniques in land cover dynamics. ISPRS Int. J. Geo-Inf. 2013, 2, 577-597. [CrossRef]

41. Couture, R.; Blais-Stevens, A.; Bobrowsky, P.; Wang, B.; VanDine, D. Canadian technical guidelines and best practices related to landslides: A national initiative for loss reduction. In Landslides: Global Risk Preparedness; Springer: Berlin, Germany, 2013; pp. 315-322.

42. Merghadi, A.; Abderrahmane, B.; Tien Bui, D. Landslide Susceptibility Assessment at Mila Basin (Algeria): A Comparative Assessment of Prediction Capability of Advanced Machine Learning Methods. ISPRS Int. J. Geo-Inf. 2018, 7, 268. [CrossRef]

43. Feizizadeh, B.; Roodposhti, M.S.; Blaschke, T.; Aryal, J. Comparing GIS-based support vector machine kernel functions for landslide susceptibility mapping. Arab. J. Geosci. 2017, 10, 122. [CrossRef] 
44. Kalantar, B.; Pradhan, B.; Naghibi, S.A.; Motevalli, A.; Mansor, S. Assessment of the effects of training data selection on the landslide susceptibility mapping: a comparison between support vector machine (SVM), logistic regression (LR) and artificial neural networks (ANN). Geomat. Nat. Hazards Risk 2018, 9, 49-69. [CrossRef]

45. Pradhan, B. A comparative study on the predictive ability of the decision tree, support vector machine and neuro-fuzzy models in landslide susceptibility mapping using GIS. Comput. Geosci. 2013, 51, 350-365. [CrossRef]

46. Yilmaz, I. Landslide susceptibility mapping using frequency ratio, logistic regression, artificial neural networks and their comparison: A case study from Kat landslides (Tokat-Turkey). Comput. Geosci. 2009, 35, 1125-1138. [CrossRef]

47. Zhou, C.; Yin, K.; Cao, Y.; Ahmed, B.; Li, Y.; Catani, F.; Pourghasemi, H.R. Landslide susceptibility modeling applying machine learning methods: A case study from Longju in the Three Gorges Reservoir area, China. Comput. Geosci. 2018, 112, 23-37. [CrossRef]

48. Yilmaz, I. The effect of the sampling strategies on the landslide susceptibility mapping by conditional probability and artificial neural networks. Environ. Earth Sci. 2010, 60, 505-519. [CrossRef]

49. Vapnik, V. The Nature of Statistical Learning Theory; Springer Science \& Business Media: New York, NY, USA, 2013.

50. Cramer, H. Mathematical Methods of Statistics; Princeton University: Princeton, NJ, USA, 1946.

51. Salvatici, T.; Tofani, V.; Rossi, G.; D’Ambrosio, M.; Stefanelli, C.T.; Masi, E.B.; Rosi, A.; Pazzi, V.; Vannocci, P.; Petrolo, M. Application of a physically based model to forecast shallow landslides at a regional scale. Nat. Hazards Earth Syst. Sci. 2018, 18, 1919-1935. [CrossRef]

52. Aleotti, P. A warning system for rainfall-induced shallow failures. Eng. Geol. 2004, 73, 247-265. [CrossRef]

53. Zhang, X.; Yang, F. RClimDex (1.0) user manual. Clim. Res. Branch Environ. Can. 2004, 13-21.

54. Segoni, S.; Tofani, V.; Rosi, A.; Catani, F.; Casagli, N. Combination of rainfall thresholds and susceptibility maps for dynamic landslide hazard assessment at regional scale. Front. Earth Sci. 2018, 6, 85. [CrossRef]

55. Segoni, S.; Lagomarsino, D.; Fanti, R.; Moretti, S.; Casagli, N. Integration of rainfall thresholds and susceptibility maps in the Emilia Romagna (Italy) regional-scale landslide warning system. Landslides 2015, 12, 773-785. [CrossRef]

56. Auflič, M.J.; Šinigoj, J.; Krivic, M.; Podboj, M.; Peternel, T.; Komac, M. Landslide prediction system for rainfall induced landslides in Slovenia (Masprem). Geologija 2016, 59, 259-271. [CrossRef]

57. Kayastha, P.; Dhital, M.R.; De Smedt, F. Evaluation of the consistency of landslide susceptibility mapping: A case study from the Kankai watershed in east Nepal. Landslides 2013, 10, 785-799. [CrossRef]

58. IPCC-SR15. Global Warming of $1.5{ }^{\circ} \mathrm{C}$. Intergovernmental Panel on Climate Change (IPCC). Available online: http:/ / www.ipcc.ch/report/sr15/ (accessed on 22 October 2018).

59. Ahmed, B.; Kelman, I. Measuring Community Vulnerability to Environmental Hazards: A Method for Combining Quantitative and Qualitative Data. Nat. Hazards Rev. 2018, 19, 4018008. [CrossRef]

60. Persits, F.M.; WAndrey, C.J.; Milici, R.C.; Manwar, A. Digital Geologic and Geophysical Data of Bangladesh; U.S. Geological Survey (USGS): Reston, VA, USA, 1997.

(C) 2018 by the authors. Licensee MDPI, Basel, Switzerland. This article is an open access article distributed under the terms and conditions of the Creative Commons Attribution (CC BY) license (http:// creativecommons.org/licenses/by/4.0/). 